\title{
Cosmopolítica indígena nos Andes:
}

\section{reflexões conceituais para além da "política"1}

\author{
Marisol de la Cadena \\ University of California, Davis
}

\section{Tradução: Lucas da Costa Maciel e Fernanda Borges Henrique}

\section{Resumo}

$\mathrm{Na}$ América Latina, a política praticada pelos povos indígenas tem sido classificada como "política étnica". Seu ativismo é interpretado como uma questão de fazer prevalecer direitos culturais. Mas e se "cultura" for uma noção insuficiente, e até mesmo inadequada, para pensar o desafio que a política indígena representa? Inspirado nos eventos políticos recentes no Peru - e, em menor medida, no Equador e na Bolívia em que o movimento indígena-popular tem evocado entidades sencientes (montanhas, água e terra - aquilo que chamamos de "natureza") para o interior da esfera da política pública, o argumento deste ensaio possui três dimensões. Primeiro, a indigeneidade, como uma formação histórica, excede a noção usual de política, isto é, uma arena povoada de seres humanos racionais disputando o poder de representar outros humanos frente ao Estado. Segundo, a atual emergência política da indigeneidade — nos movimentos de oposição antimineração no Peru e no Equador, mas também em eventos comemorativos na Bolívia - desafia a separação entre natureza e cultura que sustenta a noção predominante de política e seu contrato social correspondente. Terceiro, para além da "política étnica", os movimentos indígenas atuais propõem uma prática política diferente, plural não porque promovida por corpos marcados por gênero, raça, etnicidade ou sexualidade (como o multiculturalismo entenderia), mas porque evocam não humanos como atores na arena política.

Palavras-chave: natureza-cultura, política indígena, movimentos anti-mineração, cosmopolítica, pluriverso, Andes,

\section{Abstract}

In Latin America indigenous politics has been branded as "ethnic politics." Its activism is interpreted as a quest to make cultural rights prevail. Yet, what if "culture" is insufficient, even an inadequate notion, to think the challenge that indigenous politics represents? Drawing inspiration from recent political events in Peru — and to a lesser extent in Ecuador and Boliviawhere the indigenous-popular movement has conjured sentient entities (mountains, water, and soil—what we call "nature") into the public political arena, the argument in this essay is threefold. First, indigeneity, as a historical formation, exceeds the notion of politics as usual, that is, an arena populated by rational human beings disputing the power to represent others vis-à-vis the state. Second, indigeneity's current political emergence-in oppositional antimining movements in Peru and Ecuador, but also in celebratory events in Boliviachallenges the separation of nature and culture that underpins the prevalent notion of politics and its according social contract. Third, beyond "ethnic politics" current indigenous movements, propose a different political practice, plural not because of its enactment by bodies marked by gender, race, ethnicity or sexuality (as multiculturalism would have it), but because they conjure nonhumans as actors in the political arena.

Keywords: nature-culture, indigenous politics, antimining movements, cosmopolitics, pluriverse, Andes, Latin America.

América Latina.

$1 \quad$ Nota dos tradutores. O original deste texto foi publicado em inglês sob o título de "Indigenous Cosmopolitics in the Andes: Conceptual Reflections beyond 'Politics"', na Revista Cultural Anthropology, vol. 25, núm. 2, pp. 334-370, no ano de 2010. Agradecemos a revisão técnica de Salvador Schavelzon e as revisões de estilo de Arianne Rayis Lovo, Karine Assumpção e Janaína Tatim. 
É inconcebível que, no século 21, Deus ainda tenha que ser definido de acordo com os parâmetros europeus... Nós pensamos que a vida de Jesus é a Grande Luz vinda do Inti Yaya (luz paterna e materna que a tudo mantém), cujo intuito é deter tudo aquilo que não nos permite viver a justiça, a irmandade entre os seres humanos e em harmonia com a Mãe Natureza... O papa deveria entender que nossa religião NUNCA MORREU, nós aprendemos como mesclar nossas crenças e símbolos com aqueles dos invasores e

opressores.

- Humberto Cholango, Maio de $2017^{2}$

Como apresentar uma proposição cujo desafio não é o de dizer o que ela é, nem de dizer o que ela deve ser, mas de fazer pensar; e que não requer outra verificação senão esta: a forma como ela terá "desacelerado” os raciocínios cria a ocasião de uma sensibilidade um pouco diferente no que concerne aos problemas e situações que nos mobilizam? — Isabelle Stengers, $2005^{3}$

2 Posição da Confederação dos Povos de Nacionalidade Kichwa do Equador frente às declarações dadas por Benedito XVI na V Conferência de Bispos da América Latina e do Caribe (Celam), em maio de 2017. Documento eletrônico, http://www. altercom.org/article148222.html, acessado em: 01/05/2010.

3 Nota dos tradutores. Trecho retirado da página 443 da tradução de Raquel Camargo e Stelio Marras ao português, disponível em STENGERS, Isabelle. A proposição cosmopolítica. Revista do Instituto de Estudos Brasileiros, n. 69, p. 442-464, 2018. 
A reconfiguração política atualmente em curso na América Latina pode marcar mudanças de época no continente. Os resultados eleitorais na Bolívia e no Equador levaram analistas internacionais e nacionais a interpretar essas mudanças como um retorno (sub)continental à esquerda. No entanto, o que é inédito é a presença de movimentos sociais indígenas regionais como um elemento constitutivo dessas transformações. Suas demandas tendem a perturbar agendas políticas e disposições conceituais, tanto progressivas quanto conservadoras.

Considere a primeira citação acima, retirada de uma carta que Humberto Cholango, o Presidente da Ecuarunari - uma organização política indígena do Equador —, escreveu para o Papa Benedito XVI em maio de 2007. Em uma reunião no Brasil, o Papa disse que, à época da conquista, os índios já ansiavam pela sua conversão, e que esta não teria sido violenta; a carta do Cholango protesta contra tais declarações. Complexo documento político, a carta consistiu em denúncia, promoção de alianças e proposta de uma agenda distinta. Cholango denunciou os mais de quinhentos anos de colonização pela dominante Igreja Católica, assim como a postura neoimperial de George W. Bush, então Presidente dos Estados Unidos da América. Ambos coincidem nas suas consequências genocidas frente aos modos de vida na América Latina, diz o documento. Contra estas consequências, Ecuarunari forjou alianças com os teólogos da libertação e os assim chamados presidentes de esquerda da região. Significativamente, o documento alertou a todos que, contra a vontade dos colonizadores, as práticas indígenas sempre estiveram lá; elas continuam fortes e atualmente guiam o projeto político em Abya Yala, o nome com o qual os movimentos sociais indígenas se referem à América Latina.

As práticas que Cholango mencionou podem ser identificadas como religiosas (de fato, ele também o faz); ainda assim, a carta muda o problema ao distender práticas religiosas de um interesse exclusivo pelo sagrado ou espiritual para localizá-las no interior de temáticas políticas, mundanas e históricas de coabitação entre católicos e não católicos, instituições indígenas e não indígenas. Transformando o problema, a carta desloca a conversa do âmbito das crenças religiosas transcendentais para um plano de imanência e ontologia histórica emaranhado à política indígena organizada. De forma fundamental, o problema analítico que a carta revela é o de que a política indígena pode exceder a política como conhecemos. Políticos consagrados têm dificuldade em aceitar que, por exemplo, "Jesus, a Grande Luz vinda do Inti Yaya," tenha conexões tangíveis, tanto com a "Mãe Natureza", quanto com os seres humanos. Além do mais, Inti Yaya e Mãe Natureza, até então estranhas à política, podem ser convocadas para o seu interior e até mesmo deixarem suas marcas no mais oficial dos documentos estatais. Para a surpresa de muitos, no Capítulo 7 da Constituição da República do Equador de 2008, se lê4: "A Natureza ou a Pachamama, onde a vida se torna real e se reproduz, tem o direito de ser integralmente respeitada em sua existência, e à manutenção e regeneração dos ciclos vitais, estruturas, funções e processos

4 Nota dos Tradutores. Corresponde ao trecho inicial do artigo 71 da Constituição da República do Equador. O original em espanhol seria "La naturaleza o Pacha Mama, donde se reproduce y realiza la vida, tiene derecho a que se respete integralmente su existencia y el mantenimiento y regeneración de sus ciclos vitales, estructura, funciones y procesos evolutivos". 
evolutivos" (ênfase minha) $)^{5}$ Que a natureza tenha direitos pode (até) ser entendido através da gramática ambientalista. Mas o que é a Pachamama e o que aconteceu que permitiu à entidade uma presença na Constituição?

Claramente irritado, Rafael Correa, presidente do Equador e, às vezes, antineoliberal, culpou uma coalizão "infantil" de ambientalistas, esquerdistas e indigenistas pela intromissão da Pachamama-Natureza na Constituição. Finalizando sua acusação, ele adicionou que essa coalizão era o principal perigo para o processo político equatoriano (OSPINA, 2008) ${ }^{6}$. A reação não é incomum entre políticos como Correa: modernos, urbanos e autoidentificados como não indígenas, eles recusam o excesso como residual (ou infantil, neste caso) e esperam que ele gradativamente desapareça. No entanto, como insiste Cholango, aquilo que ele chama de suas "crenças e símbolos" não desapareceram em quinhentos anos. Convocar estes atores inusitados pode de fato ser uma estratégia política para interpelar as subjetividades indígenas. Não obstante, a estratégia poderia ter, ela mesma, uma explicação ontológica própria? Podemos pensar sobre estas presenças como atores políticos - ou, no mínimo, como uma questão política — ao invés de invalidá-las como excessivas, residuais ou infantis? Como podemos fazer isso? Estas questões parecem inusitadas; elas perturbam as zonas de conforto conceituais. Elas emergem dos desafios conceituais colocados pelas presenças igualmente inusitadas, não de políticos indígenas, mas das entidades (que eu chamo de "seres-terra") que eles conjuram no interior da esfera política.

$\mathrm{O}$ aparecimento dos seres-terra nos protestos sociais poderia evidenciar um momento de ruptura da política moderna e de uma indigeneidade emergente ${ }^{7}$. Eu não me refiro a um novo modo de ser indígena, mas a uma insurgência de forças e práticas indígenas com a capacidade de perturbar profundamente as formações políticas prevalentes, e de rearranjar os antagonismos hegemônicos, sobretudo ao deslegitimar (e, portanto, desnaturalizar) a exclusão das práticas indígenas das instituições do Estado-nação. Embora possa ser reabsorvido em uma nova hegemonia política, o momento atual representa uma conjuntura histórica única. Emergindo através de uma crise profunda, expansiva e simultânea do colonialismo e do neoliberalismo (BLASER, 2007) - convergindo em suas frentes ecológica, econômica e política - a presença pública de atores incomuns à política é, no mínimo, instigante. Ela poderia representar uma ocasião epistêmica para "desacelerar a razão" - como na citação de Stengers acima - e em lugar de proferir afirmações, adotar uma atitude intelectual que propõe e, portanto, produz possibilidades para novas interpretações. Tomando a sugestão de Stengers, eu concebo este ensaio de inspiração etnográfica como um convite a levar a sério (talvez literalmente) a presença desses atores na política, os quais,

5 Conferir http://www.eluniverso.com/2008/07/24/1212/1217/E8C064BD52EF420CAECDB655555BF60C.html, acessado em 09/09/2019.

6 Agradeço a Eduardo Gudynas por me indicar este documento.

7 Eu emprestei a ideia da noção de "formas de vida emergentes", do Michael Fisher, usada por ele para discutir novos trabalhos nas ciências biológicas e os resultados políticos, éticos, teóricos e empíricos que se desprendem deles. Meu empréstimo de tal noção torna explícita a ênfase na copresença histórica, e até mesmo o entrelaçamento global, entre as práticas científicas correntes e os modos indígenas de habitar o mundo. 
sendo outros que humanos ${ }^{8}$, são atribuídos, pelas disciplinas dominantes, ou à esfera da natureza (onde eles deveriam ser conhecidos pela ciência), ou aos campos metafísicos e simbólicos do conhecimento (WILLIAMS, 1977: 125).

Pampamisayoq. Minha compreensão sobre as relações entre humanos e seres-terra vem de dois indivíduos quéchua, Mariano Trupo e seu filho, Nazario. Eles viviam numa remota vila no Peru chamada Pacchanta, localizada a mais de 15.000 pés acima do nível do mar, a sudeste da cidade de Cuzco. Mariano estava próximo dos noventa anos quando eu o conheci, em 2002; ele faleceu em razão da sua idade avançada dois anos mais tarde. Nazario e eu continuamos trabalhando juntos até que um acidente de carro tragicamente terminou com a sua vida, em julho de 2007. Ambos eram pampamisayoq (normalmente traduzido como "especialistas rituais") e políticos. (Uma tradução literal de pampamisayoq seria "aquele com a misa ou a montanha" e, portanto, capaz de interagir com a pampa, ou aquilo que chamamos de paisagem.) Eles não eram tradicionalistas isolados; ao contrário, ambos eram viajantes experientes e inovadores locais. Quando era mais jovem, o ativismo do Mariano o levou a Lima, onde se encontrou com funcionários do Estado, incluindo o presidente peruano. Nazario viajou ainda mais longe ao Museu Nacional do Índio Americano, em Washington D.C., onde ele foi curador de uma exibição andina. Ele também participou de encontros no Equador e na Bolívia organizados pela rede regional de movimentos sociais indígenas. Através deles, o Peru continua sendo meu foco etnográfico, ainda que eu também explore eventos na Bolívia e no Equador. Em lugar de um evento limitado à esfera nacional, a atual emergência da indigeneidade está sendo levada a cabo por meio de uma rede regional de ativismo e prática cotidiana.

\section{"Práticas excessivas" se proliferam e perturbam "A política como de costume"}

Ao mesmo tempo em que se abre o século XXI, as interações entre seres-terra e humanos — aquilo que Penelope Harvey (2007) chama de "práticas da terra" [earth-practices] — são presenças cada vez mais frequentes no palco político andino. Na Bolívia, "oferendas à Pachamama" (conhecidas como pagos, despachos ou misas) ${ }^{9}$ se tornaram públicas durante as mobilizações políticas conhecidas como a Guerra da Água e a Guerra do Gás, ocorridas em 2000 e 2003, respectivamente, e que aceleraram o fim de dois governos neoliberais consecutivos no país. Em 21 de janeiro de 2006, um dia antes da posse de Evo Morales como o novo presidente da Bolívia, um grupo de anciãos Aymara o reconheceu como seu líder numa cerimônia pública que evocou a paisagem

8 Nota dos tradutores. Optamos pela tradução "outros que humanos" para a expressão em inglês other-than-human, seguindo a opção tradutória de Jamille Pinheiro Dias em DE LA CADENA, Marisol. 2018. Natureza incomum: histórias do antropo-cego. Revista do Instituto de Estudos Brasileiros, n. 69, p. 95-117, 2018.

9 Tratam-se de pequenos pacotes de comida presenteados, através de sua incineração, à paisagem circundante. 
do entorno ${ }^{10}$. Depois disso, práticas similares - libações para a terra antes de um debate político, por exemplo - entraram nos principais departamentos do Estado Boliviano, atraindo a atenção internacional, inclusive. Uma história contada no Wall Street Journal (CÓRDOBA; LUHNOW, 2006), intitulada "Uma Pitada de Misticismo: Governando a Bolívia ao Modo Aymara", de julho de 2006, relatou que David Choquehuanca, o ministro do exterior da Bolívia, introduziu "crenças" andinas em sua função. Poderíamos ser tentados a interpretar a frequência dessas práticas como uma expressão da momentânea (alguns desejariam que efêmera) "política étnica organizada" na Bolívia. Entretanto, o mesmo raciocínio não se aplica ao Equador, dado que, tanto a carta de Cholango para o Papa, quanto a inscrição da "Natureza ou Pachamama" na Constituição ocorreram apesar da derrota eleitoral de Luis Macas, o candidato indígena à Presidência do Equador em 2006. Além do mais, o fato de práticas similares terem aparecido na esfera política do Peru - excepcional entre os países andinos porque a política étnica tem pouca aceitação — sugere uma composição mais complexa do que a de uma política organizada (de esquerda ou étnica) articulando sua emergência. Dei-me conta disso após comparecer a uma manifestação política que descrevo a seguir.

No começo de dezembro de 2006, mais de mil camponeses se reuniram na praça principal de Cuzco, a Plaza de Armas. Eles provinham dos vilarejos localizados aos pés da montanha chamada de Ausangate, bastante conhecida em Cuzco como um poderoso ser-terra, fonte da vida e da morte, da riqueza e da miséria; de modo que obter um resultado favorável requer que se mantenham relações adequadas com ele e com seus arredores (outras montanhas, entidades menos sencientes). Na Plaza de Armas, os camponeses se juntaram a outros manifestantes: centenas de devotos do Santuário Coyllur Rit'i e membros das irmandades católicas que tomam conta do lugar. Todos eles estavam ali para protestar contra a concessão de prospecção para uma mina localizada em Sinakara, uma das montanhas que compõem a cadeia à qual Ausangate pertence e que também abriga o Coyllur Rit'i. Visitado anualmente por milhares de peregrinos de toda a região de Cuzco, o santuário comemora a aparição do divino pastor e da cruz milagrosa. Elemento corrente nas manifestações de base em Cuzco, a Plaza estava repleta de pessoas vestindo ponchos e chullos (gorros multicoloridos feitos de lã) marcadamente indígenas. Como também é comum, haviam faixas; algumas delas mostravam lemas culturais-ambientais apropriadas para a ocasião: "Nós defenderemos nosso patrimônio cultural com nossas vidas: não à mina!" Mas também havia estandartes pouco usuais, do tipo carregado pelos porta-bandeiras durante as peregrinações ao próprio Coyllur Rit'i. Igualmente intrigante, entre os manifestantes estavam, desta vez, ukukos, dançarinos rituais e personagens centrais nas peregrinações. Dançarinos rituais e congregações rurais e urbanas participando como tais de uma manifestação política... Eu nunca tinha visto algo similar naquela Plaza, lugar em que participei de inúmeras e diversas manifestações políticas ao longo de vários anos.

No entanto, o grau em que essa demonstração foi diferente de outras me foi evidenciado 
pelo meu amigo Nazario, provindo do vilarejo Pacchanta, que fica aos pés de Ausangate. Ele estava ali para protestar contra o projeto de mineração - na verdade, ele me ligou para alertar sobre o evento. Inicialmente, enquanto protestávamos, eu pensei que compartilhássemos uma visão única sobre a mina; no entanto, quando nos debruçamos cuidadosamente sobre a manifestação e como ela poderia influenciar eventos futuros, me dei conta de que nossa visão compartilhada era também mais do que uma. A razão pela qual me opunha à mina se devia ao fato de que ela poderia destruir as pastagens das quais as famílias dependem para ganhar a vida criando alpacas e ovelhas, e vendendo sua lã e sua carne. Nazario concordou comigo, mas disse que seria pior: Ausangate não permitiria que uma mina se instalasse em Sinakara, uma montanha sob sua influência. Ausangate ficaria furioso, podendo inclusive matar pessoas. Para prevenir tal matança, a mina não deveria ser construída. Eu não poderia estar mais de acordo, e ainda que eu não conseguisse conceber que Ausangate pudesse matar, foi impossível considerar o que havia sido dito como uma metáfora. Prevenir a ira de Ausangate era a motivação de Nazario para participar na manifestação e, neste sentido, ela teve importância política.

Dias depois, e de volta à zona rural, percebi que, de uma forma ou de outra, muitos compartilhavam de sua visão. Entre essas pessoas, alguns eram camponeses, outros comerciantes; alguns autoidentificados como indígenas, outros não. Algumas personalidades locais (o prefeito, o juiz de paz, professores, comerciantes) estavam divididas — não sobre a sensicência de Ausangate, mas sobre os possíveis perigos da sua reação, incluindo deslizamentos de terra, epidemias e secas, e sobre as formas de negociar e lidar com ele. Em 2008, quando visitei Pacchanta, o vilarejo de Nazario Turpo, haviam rumores de que o projeto de mineração havia sido cancelado. Talvez não teria sido um empreendimento de sucesso, dizia o burburinho, e Ausangate havia se retirado da esfera política. Durante essa visita, eu também conversei com Graciano Mandura, o prefeito recém-eleito de Ocongate - o distrito que contém o complexo Coyllur Rit'i-Sinakara-Ausangate. Nascido em Pacchanta, como Nazario, Graciano é um falante nativo de quéchua que aprendeu o espanhol na escola primária, é formado em pecuária pela Universidade de Cuzco e estava trabalhando para uma ONG local quando decidiu concorrer ao cargo de prefeito. Como candidato, Graciano se juntou aos esforços contra a mina, que ameaçava o santuário e a cadeia de montanhas; na nossa conversa, eu lhe perguntei por que ele havia se juntado ao empenho antimineração, e ele explicou que a mina retrairia o turismo, uma atividade que estava gerando renda para a região. Esta era uma resposta que eu esperava. No entanto, ele acrescentou que sabia por experiência que as montanhas, que ele chamou por seus nomes, exigiam respeito. Senão, acidentes inexplicáveis aconteceriam - sempre tinha sido assim. Não seria sua responsabilidade, como prefeito, prevenir tais acidentes, seja qual for sua razão? Ora, essa resposta - e mais especificamente sua formulação através da lógica da responsabilidade de um funcionário do Estado — confirma que havia, nesta localidade, mais do que a política como de costume ${ }^{11}$. Desacelerar o raciocínio era

11 Nota dos tradutores. Politics as usual é a expressão que traduzimos por "política como de costume". Com ela, a autora quer indicar a política geralmente entendida e em curso a partir dos conceitos, instituições e modos relacionais moderno-ocidentais, que, conforme argumenta o artigo, pretendem excluir da política os seres-terra tais como Ausangate. Em certo sentido, então,

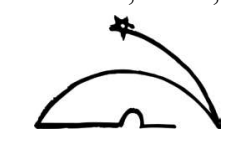


etnograficamente necessário.

Ausangate e o santuário de Coyllur Rit'i não são os únicos seres-terra a se tornarem politicamente públicos. No norte do Peru, uma coalizão de camponeses e ambientalistas tornaram público o Cerro Quilish como uma "montanha sagrada" e engajada na luta contra Yanacocha, a maior mina de ouro da América Latina ${ }^{12}$. Eu retomo uma breve discussão desse evento adiante. Por enquanto, é suficiente dizer que, ainda que nem todo conflito por mineração que prolifera no Peru articule a presença dos seres-terra, os poucos que se tornaram públicos foram suficientemente influentes para incomodar o presidente Alan García. Montanhas sagradas, disse ele, foram uma invenção de "velhos comunistas anticapitalistas do século dezenove que se tornaram protecionistas no século vinte e que, mais uma vez, se transformaram em ambientalistas no século vinte e um"13. Esses lugares, continua, não eram mais do que terras ociosas, cujos "donos não têm qualquer formação ou recursos econômicos, de tal modo que suas propriedades não são reais". Ainda que especialistas de esquerda tenham respondido aos muitos pontos neoliberalizantes de García, não disseram nada sobre as montanhas sagradas. Talvez eles pensem que o presidente esteja certo sobre este tema; lugares sagrados são um disparate, uma curiosidade que se espera logo desapareça. Se eu quiser contestar a posição de García (e convencer pelo menos alguns dos meus amigos de esquerda no processo), onde devo procurar por um caminho que leve a uma discussão com alguma possibilidade de se tornar frutífera?

A economia política e a política cultural certamente oferecem pontos de entrada. É inegável que o neoliberalismo seja um ator importante neste jogo; as políticas de livre mercado, a precificação global dos minérios e as atividades de mineração cresceram dramaticamente no Peru. Entre 1990 e 2000, os investimentos em mineração quintuplicaram; entre 1990 e 2003, as exportações de minerais cresceram de 1.447 milhões de dólares para 4.554 milhões. Em 2002, o Peru era o líder em produção de ouro na América Latina e o sexto maior produtor a nível mundial. As concessões para atividades de mineração aumentaram rapidamente, crescendo em $77.4 \%$ entre 2002 e 2007, de 7.015.000 hectares para 13.224.000 hectares. Muitas dessas novas concessões foram dadas em territórios onde a mineração não tem uma ocorrência histórica e que são frequentemente ocupados por comunidades indígenas ${ }^{14}$. Esses números são impactantes o suficiente para explicar a intensificação dos protestos antimineração. Qualquer um poderia se sentir tentado a interpretar esses eventos sob os parâmetros da economia política e do vocabulário analítico que ela disponibiliza. Eu poderia, por exemplo, ver as manifestações antimineração como respostas indígenas à expropriação de suas terras, ou como o resultado de algo como uma "consciência ambiental". Esta perspectiva seria compatível com uma análise etnográfica das políticas culturais

politics as usual poderia ter sido traduzido como "política hegemônica".

12 A Yanacocha é de propriedade da Newmont Mining Corporation (com sede em Denver, Colorado, Estados Unidos), da companhia peruana Minas Buenaventura e da International Finance Corporation (o braço financeiro do Banco Mundial) (LI, 2009).

13 Ver El Comercio, 28/10/2007, A4.

14 Ver Bebbington e Burneo (2008) e Hilson e Haslip (2004). 
que se distancia de uma etnografia andinista anterior que, como Orin Starn afirmou há muitos anos atrás, tem sido habitualmente rica em análises rituais e simbólicas e alheia em relação à política $(1991)^{15}$. Analisar a copresença de ambos - rituais andinos confrontando as políticas dominantes de propriedade, por exemplo — poderia somar a uma contribuição acadêmica.

Outra tentação analítica: eu poderia ver esses eventos como desafios indígenas para a secularização do Estado, lembrando-nos que "a religião do governante não é a religião dos sujeitos" (ASAD, 2005), e que eles, ao contrário, forjam uma contra esfera pública indígena (FRASER, 1997; para Bolívia ver ALBRO, 2006; STEPHENSON, 2002). Tais interpretações não seriam imprecisas - elas poderiam ser uma sorte de resposta a posições como a de Alan García, o presidente peruano. Contudo, o que é acurado não é necessariamente suficiente (cf. CHAKRABARTY, 2000) e os questionamentos permanecem. Quais tipos de públicos estão sendo mobilizados para a esfera política e por que eles a atrapalham? Respostas a essas perguntas que partam da ideologia como ponto de análise parecem curtas: a diferença entre Rafael Correa, presidente do Equador, e Humberto Cholango, porta-voz da Ecuarunari, parece ser mais do que ideológica; diferenças importantes persistem entre os dois, mesmo quando o presidente, pelo menos por vezes, parece ter inclinações à esquerda. Mensurar tais diferenças em "graus de esquerdismo" seria, penso eu, se não falho, pelo menos uma perda de tempo. De forma similar, a ideologia não explica a diferença entre o ex-presidente peruano Alan García, um modernizador neoliberal, e Nazario Turpo, que não atribui suas causas a uma ideologia política de maneira definitiva. Além disso, como explicamos a coincidência entre o inflexível presidente neoliberal García e o presidente (até agora) antineoliberal Correa, ambos irados com a presença de, digamos, atores "excessivos" nos palcos das políticas nacionais? O que se segue é uma tentativa de desnaturalizar esse excesso, propondo uma compreensão histórica dos processos epistêmico-políticos do qual ele se desdobra.

\section{A teoria política que baniu os seres-terra da política}

O mundo político é um pluriverso, não um universo.

- Schmitt, 1996

A política não é feita de relações de poder; ela é feita de relações entre mundos.

- Rancière, 1999

15 Os comentários de Starn provocaram uma forte reação por parte dos andinistas que ele criticou. Suas respostas enfatizaram seu entendimento limitado da relevância política dos seus trabalhos (veja, por exemplo, MAYER, 1991). Do meu ponto de vista, tanto os trabalhos que Starn criticou, quanto seu trabalho de crítica, se desenvolvem dentro do marco da divisão entre "natureza" e "cultura" que este ensaio refuta. Na literatura andinista que Starn criticou, os seres-terra e as relações com eles são "interpretações culturais" da "natureza". Neste tipo de formulação, Ausangate aparece como uma montanha - não há espaço para a discussão política de sua ontologia como um ser outro que humano. Ambas as partes teriam, naquele momento, concordado neste ponto. Outra concordância entre as partes em disputa: Starn enquadrou sua preocupação sobre a falta de estudos etnográficos da política subalterna através da noção de política "como de costume", aqueles que ele criticou argumentaram pela relevância política dos seus trabalhos - na defesa dos direitos culturais, por exemplo - utilizando a mesma noção. 
Uma leitura da etnografia andinista guiada pelas questões epistêmicas mostra que as "práticas da terra" são relações para as quais a distinção ontológica dominante entre humanos e natureza não funciona ${ }^{16}$. As "práticas da terra" promulgam o respeito e o afeto necessários para manter a condição relacional entre seres humanos e outros que humanos os quais produzem a vida nos (e em muitas partes dos) Andes. Outros que humanos incluem animais, plantas e a paisagem. Esta última, a mais frequentemente convocada na política atual, se compõe de uma constelação de seres sencientes conhecidos como tirakuna, ou seres-terra, com fisionomias individuais mais ou menos conhecidas pelos indivíduos envolvidos nas interações com eles ${ }^{17}$. As "coisas" que os movimentos indígenas estão hoje "tornando públicas" (cf. LATOUR, 2005) na política não são simplesmente não humanos; são também entidades sencientes cuja existência material - e aquela dos mundos aos quais pertencem - está atualmente ameaçada pelo matrimônio neoliberal entre o capital e o Estado. Assim, quando as montanhas - Quilish ou Ausangate, digamos - emergem no âmbito da política, eles o fazem como seres-terra, "objetos controversos cujo modo de apresentação não é homogêneo ao modo ordinário de existência dos objetos pelos quais eles, a partir de então, são identificados" (RANCIÈRE, 1999: 99). Tomando emprestado da história da ciência para traçar a história da política (já que a primeira, tanto quanto a última, foram inventadas), proponho que esses objetos são controversos porque sua presença na política nega a separação entre "Natureza" e "Humanidade", na qual está historicamente fundada a teoria política à qual nosso mundo se sujeita18.

De acordo com a ordem moderna das coisas, a ciência e a política são como a água e o óleo: não se misturam. A primeira implica uma representação objetiva da natureza, enquanto a segunda é a negociação do poder para representar pessoas frente ao Estado. Essa distinção, explicam os historiadores da ciência Steven Shapin e Simon Schaffer, resultou da discussão entre Hobbes, autor de Leviatã, e Robert Boyle, defensor do "experimento" como método científico e arquiteto do novo campo da ciência experimental e suas instituições sociais (SHAPIN, SCHAFFER, 1985). Eles propõem que esta discussão (na qual Hobbes negou a verdade do experimento de Boyle por causa de sua natureza privada, e Boyle insistiu que experimentos não poderiam ter o aspecto público que deveria caracterizar a política) foi um momento histórico importante na invenção da linguagem que removeu a "política" da "ciência", e da consequente formulação das fronteiras

16 Muitos acadêmicos têm escrito sobre seres sencientes outros que humanos; ver, por exemplo, Abercrombie (1998), Allen (2002), Earls (1969), Flores-Ochoa (1977), Gose (1994), Harris (2000), Harvey (2007), Nash (1993), Platt (1997), Ricard-Lanatta (2007), Sallnow (1987), Taussig (1988), Valderrama-Escalante (1988). Não obstante, e ainda que alguns desse autores discutam a participação dos seres-terra na política local e as negociações humanas com eles (por exemplo, NASH, 1993; PLATT, 1997; TAUSSIG, 1988), nenhum desses estudos considera esses seres como potenciais atores da política nacional, menos ainda como suas diferentes ontologias rompem com o campo conceitual da política. Seres outros que humanos pertencem, na literatura etnográfica, à "cultura indígena”, não a um desentendimento potencial que toma lugar naquilo que Mario Blaser (2009) chama de ontologia política. Este ensaio se constrói sobre esta rica literatura etnográfica, questionando, ao mesmo tempo, a política ontológica que a possibilita e a circunscreve como cultura. Sua hegemonia é difícil de se desfazer; nosso apego disciplinário à cultura opera de forma profundamente afetiva - eu certamente me incluo nesse comentário.

17 Tirakuna é o plural quechualizado para a palavra tierra, em espanhol, terra. Para uma análise detalhada da relação entre os tirakuna e as pessoas, ver Allen (2002).

18 As explicações antropológicas sobre os seres-terra valendo-se da metafísica ocidental ou da religião (o animismo, por exemplo) pertencem à mesma teoria política. Portanto, os seres-terra são possíveis como espíritos, mas os espíritos não pertencem à política. 
entre a epistemologia e as forças da sociedade. Bruno Latour (1993) baseia-se nesta análise para desenvolver seu argumento sobre a criação do que ele chama de Constituição Moderna: o regime de vida que criou uma única ordem natural e separou-a do social, gerando uma distinção ontológica entre as coisas e os seres humanos que se pretendia universal. Ele sugere que, em vez de criar duas esferas separadas - a ciência de Boyle e a política de Hobbes - o que estes autores fizeram juntos (através de sua discussão) foi criar "nosso mundo moderno, um mundo no qual a representação das coisas através do laboratório encontra-se para sempre dissociada da representação dos cidadãos através do contrato social" (LATOUR, 1993: 27). Hobbes e Boyle são, assim, "dois pais fundadores, agindo em conjunto para promover uma única e mesma inovação na teoria política: cabe à ciência a representação dos não-humanos, mas lhe é proibida qualquer possibilidade de apelo à política; cabe à política a representação dos cidadãos, mas lhe é proibida qualquer relação com os não-humanos produzidos e mobilizados pela ciência e pela tecnologia"19 (LATOUR, 1993: 28).

A presença dos seres-terra nos protestos sociais nos convida a desacelerar o raciocínio, pois pode evidenciar um momento intrigante de ruptura epistêmica com essa teoria política. Sua emergência se desentende - para usar a expressão de Rancière - tanto com a política quanto com a ciência; isso pode perturbar o lugar de enunciação do que é "política" - quem pode ser um ator político ou o que pode ser considerado uma questão política e, assim, embaralhar os antagonismos hegemônicos que por mais de quinhentos anos organizaram o campo político nos Andes, e que, gradualmente articulados através dos paradigmas moderno-científicos, baniram os seres-terra da política. Aqui tomei emprestada a distinção de Chantal Mouffe entre política e político - para a qual se baseia, por sua vez, em Carl Schmitt (MOUFFE, 2000). O antagonismo separa "amigos" de "inimigos" de tal maneira que "o adversário pretende negar o modo de vida do outro [...] a fim de preservar a sua própria forma de existência" (SCHMITT, 1996: 27). O inimigo político é "o outro, um estranho; e é suficiente para a sua natureza, de uma forma especialmente intensa, que ele seja existencialmente diferente e alheio, de tal modo que, em caso extremo, conflitos com ele sejam possíveis" (SCHMITT, 1996: 27). O antagonismo não é bom ou mal, feio ou bonito, rentável ou não rentável, pois todas essas distinções pertencem a outros campos específicos - ética, estética e economia, respectivamente - , aos quais o político não pode ser reduzido. O problema com o liberalismo, e particularmente com a democracia liberal, diz Schmitt, é que, ao vincular o político ao ético, nega o conflito e, assim, o político em si mesmo.

Mouffe retoma este ponto e baseia-se na noção de hegemonia de Gramsci para definir a política como o campo que torna habitável o antagonismo, que restringe ou até mesmo anula seu potencial bélico, sem nunca suspender o conflito que ele acarreta. As políticas são, explica Mouffe, aquelas práticas através das quais as diferenças antagônicas entre amigos e inimigos são domadas, tratadas (ideológica e institucionalmente) e transformadas em agonismo — as relações

19 Nota dos tradutores. Os trecho antes citados foram retirados das páginas 33 e 34 da tradução de Carlos Irineu da Costa ao português, disponível em LATOUR, Bruno. Jamais fomos modernos: ensaio de antropologia simétrica. Rio de Janeiro: Ed. $34,1994$. 
entre os adversários - que caracterizam ordens hegemônicas, com suas inclusões e exclusões (MOUFFE, 2000) ${ }^{20}$.

No entanto, devo acrescentar ao argumento de Mouffe que a hegemonia não atua apenas na esfera da política. O biopoder hegemônico - exercido tanto pelo socialismo quanto pelo liberalismo - transformou o político em um aceito campo de batalha pela vida. Neste campo de batalha, são tomadas decisões sobre quem são os inimigos, mas, tão importante quanto, sobre aqueles que, não resistindo ao antagonismo, sequer são dignos do estatuto de inimigo. Em certas ocasiões, estes indignos não valem a pena nem serem mortos; eles podem ser deixados para morrer porque, embora incluídos no conceito de "Humanidade", eles não contam — de forma alguma, pois estão muito próximos da "Natureza". Se o liberalismo, como sugerem Schmitt e Mouffe, vinculou o político à ética e, portanto, negou o conflito, o nascimento do campo político moderno, como aprendemos com os estudiosos da ciência, estava ligado à negação do estado da "Natureza". O que sustentou a noção do político que, eventualmente, se tornou hegemônica, foi a distinção ontológica entre "Humanidade" e "Natureza", a criação do "homem natural", sua sentença à inevitável extinção conjunta com seus seres outros que humanos e a obstrução deste antagonismo através da noção de uma "Humanidade" inflexivelmente inclusiva e hierarquicamente organizada. Somente os completamente humanos, e apenas eles, poderiam transformar suas inimizades em relações adversárias - isto é, engajar-se na política.

Inicialmente, era visível o antagonismo entre europeus e entidades outras que humanas locais. Na América hispânica, a Igreja Católica os considerava inimigos diabólicos, e práticas com seres-terra eram tratadas como idolatrias condenadas à extirpação. Na América britânica, Locke autorizou a guerra contra os nativos - sua proximidade com a natureza os tornava improdutivos, a terra tinha que ser incorporada à civilização por meio do trabalho agrícola do homem branco. $\mathrm{O}$ antagonismo deve ter sido silenciado gradualmente à medida que a razão se consolidou e acabou prevalecendo sobre a fé como um regime de conhecimento/poder, monopolizando a política para aqueles que conheciam através da ciência. A interação com as coisas através de práticas não representativas - a ausência da distinção entre significante e significado que permitia as práticas científica e política modernas - era considerada equivalente à ausência de razão e, mais especificamente, da razão política.

As reflexões de Hegel sobre a África podem servir para ilustrar este ponto. Na África, escreve Hegel, "as forças naturais, bem como o Sol, a lua, as árvores e os animais são reconhecidos como poderes por direito próprio, não são vistos como tendo uma lei eterna ou providência que os guie, ou como parte de uma ordem natural universal e permanente" (HEGEL, 1997: 130). Lá, “os reis têm ministros e sacerdotes - e algumas vezes uma hierarquia completamente organizada de funcionários - cuja tarefa é praticar a feitiçaria, comandar os poderes da natureza e determinar o tempo" (HEGEL, 1997: 130). Páginas mais adiante, ficamos sabendo que a falta de compreensão 
das "Leis da Natureza" da África era compatível apenas com uma organização política baseada na "arbitrariedade do autocrata", sujeitando "homens de temperamento igualmente selvagem" (HEGEL, 1997: 137-138). Esse raciocínio não deve ser simplificado como racismo — ele foi possibilitado pela relação antagônica que articula a distinção ontológica entre humanos e natureza. A raça (como uma ferramenta moderna para classificar a "Humanidade" ao longo de um contínuo "Civilização"-"Natureza") também foi possibilitada por essa distinção e, portanto, incluía a ideia abrangente de que a representação da "Natureza" no campo da política seria necessariamente mediada pela ciência. Hegel compartilhou com seus colegas modernos essa crença, sua base é mais profunda do que apenas o racismo.

A discriminação que possibilitou a raça (e o racismo). Uma noção hegemônica da política, construída sobre o silenciado antagonismo entre natureza e humanidade, ou legitimou ou obliterou a guerra entre o mundo dos colonizadores modernos e aqueles dos colonizados - e em nenhum caso permitiu a política entre eles. Sua visão como inimigos deslocou o potencial de uma relação antagônica, e uma luta legítima entre eles por um projeto hegemônico foi sufocada, abrindo o caminho para uma biopolítica de centro-periferia da inclusão benevolente e inevitável no progresso e na civilização. Isso produziu um regime de visibilidade (RANCIÈRE, 1999) que impediu o incalculável de aparecer como tal; a negação de sua diferença (levando à sua exclusão da possibilidade da igualdade) foi traduzida como uma inclusão classificatória na humanidade ocidental: uma oferta que "o inferior" não poderia recusar. Objeto das políticas de melhoramento, somente através de um processo de transformação (através do qual deveriam negar suas relações sociais com plantas, rios ou montanhas, por exemplo) poderiam "os naturais" ganhar acesso livre e legítimo à política. Até lá, eles eram uma ameaça (mas não exatamente um inimigo) da qual a sociedade, se quisesse viver uma vida saudável, deveria ser defendida (cf. FOUCAULT, 2003). O campo político estava discursivamente próximo da ciência da raça e o Estado mal poderia funcionar sem se envolver com o racismo (FOUCAULT, 2003: 255). Ainda que a raça tenha passado por uma constante desnaturalização teórica e histórica desde a Segunda Guerra Mundial, a discriminação entre aqueles que podem ser considerados inimigos e aqueles que não merecem tal estatuto, e entre aqueles que podem governar e aqueles que não, continua a ser legítima. Desfazer essa discriminação requer desfazer o político e a política tal como nós a entendemos - uma tarefa que requer ir além do multiculturalismo mais radical dando boas-vindas no campo político àqueles anteriormente banidos pela política racista. Gostaria de sugerir que a denúncia do racismo - mesmo seu desmantelamento — pode resolver a inferioridade em questão, mas não resolve as raízes epistêmicas do antagonismo entre aqueles com direito a governar e aqueles destinados a serem governados. O que precisa ser abordado é o estratagema epistêmico que organizou a decisão sobre o que poderia ser incluído na política e o que pertencia a outra esfera de gestão. Se o silêncio sobre a exclusão antagônica dos "naturais" estava embutido no político, a eliminação da "Natureza" da mesma esfera completou a hegemonia. 
O campo político tal como atualmente o reconhecemos foi formado não só pela distinção entre amigos e inimigos entre os humanos, mas também pela separação antitética da "Humanidade" e da "Natureza". Juntas, essas duas antíteses - entre humanidade e natureza, e entre aqueles humanos pretensamente superiores e inferiores - declararam a extinção gradual dos seres outros que humanos e os mundos nos quais eles existiam. O pluriverso, os múltiplos mundos que Schmitt considerou como cruciais à possibilidade do político, desapareceu ${ }^{21}$. Em seu lugar, um mundo único se constituiu, habitado por muitos povos (nós agora os chamamos culturas) mais ou menos distanciados de uma "Natureza" única (DESCOLA, 1996; HARAWAY, 1991; LATOUR, 1993; VIVEIROS DE CASTRO, 2004). As relações não científicas com outros que humanos foram reduzidas a crenças, distantes de um método de verificação da verdade, ainda que talvez dignas de preservação desde que não reivindiquem o direito de definirem a realidade. A relação entre mundos era de um antagonismo silencioso, com o mundo ocidental definindo para a história (e com a "História") seu papel soberbamente hegemônico como civilizacional e, como consequência, acumulando poder para organizar a vida homogênea que ele se esforçou por expandir. A política como uma relação de desentendimento entre mundos - como um "encontro dos heterogêneos", nas palavras de Rancière (1999: 32) — desapareceu, ou raramente aconteceu.

Não representacionais, as interações afetivas com outros que humanos continuaram ao longo de todo o mundo, inclusive nos Andes ${ }^{22}$. O atual aparecimento da indigeneidade andina a presença dos seres terras demandando um lugar na política — poderia implicar a insurgência dessas práticas proscritas disputando o monopólio da ciência para definir a "Natureza" e, assim, provincializando sua ontologia pretensamente universal como específica ao Ocidente: um mundo (ainda que talvez o mais poderoso deles) em um pluriverso. Esse aparecimento de indigeneidades poderia inaugurar uma política diferente, plural não porque habilitada por corpos marcados por gênero, raça, etnicidade ou sexualidade demandando direitos, ou por ambientalistas representando a natureza, mas porque eles trazem os seres-terra para a esfera do político e forçam o antagonismo que proscreveu seus mundos a se fazer visível. Ainda mais importante, isso poderia transformar a guerra, que até agora decorreu silenciosamente através de uma biopolítica do melhoramento, naquilo que Isabelle Stengers chama de cosmopolítica: uma política em que "o cosmos [...] designa o desconhecido que constitui esses mundos múltiplos, divergentes, articulações das quais eles

21 Obviamente, Schmitt também estava pensando a partir de uma noção moderna de política; assim, ele não tinha os atores outros que humanos em mente. Quando escreveu que "toda teoria do Estado é pluralista" (1996: 53), tinha em mente a pluralidade constitucional dos Estados, entidades políticas "outras" entre elas mesmas, e portanto possíveis inimigas. Também inspirado em Schmitt, Latour (2004: 278, 281) discute a qualidade de inimigos dos humanos frente aos não humanos, que o autor trata indistintamente como "coisas". Possivelmente como consequência do seu interesse pelos laboratórios e pela representação através da prática científica (e, no limite, pela vida moderna), ele desconsidera as relações com seres outros que humanos (que ele aparentemente traduz como coisas) e como práticas não representacionais.

22 As disciplinas, ainda que benevolentes, os segregaram da realidade através de categorias - superstição, crença, animismo, mito e ritual, pensamento selvagem ou religiosidade indígena - que, ao professar seu anacronismo, trataram as práticas assim descritas a partir da política moderna. 
poderiam se tornar capazes [...]"23 (STENGERS, 2005: 995). Ao criar esta articulação, os movimentos indígenas podem encontrar aqueles - cientistas, ambientalistas, feministas, igualitaristas de diferentes estirpes - também engajados com uma política diferente da natureza, uma que inclua os desentendimentos sobre a própria definição da natureza.

Antagonismo, multiculturalismo, multinaturalismo. Na América Latina, o antagonismo com a indigeneidade e os seres-terra está localizado na imagem, na retórica, nas instituições e nas práticas da "cidade letrada", um conceito bem conhecido nos estudos latino-americanos e inicialmente discutido pelo crítico literário uruguaio Ángel Rama, em La Ciudad Letrada (1969) (Uma versão em inglês foi publicada em 1996; conferir RAMA, 1996). O termo descreve o poder da alfabetização nas sociedades latino-americanas, e o papel central das cidades em sua implantação e reprodução. Mais especificamente, a alfabetização emerge a partir dos centros urbanos como uma tecnologia benevolente de melhoramento, sendo o seu impulso histórico programático deixar os índios morrerem: índio leído, índio perdido (um índio alfabetizado é um índio perdido) diz um provérbio antigo e bastante difundido na América Latina hispânica, refletindo a crença de que, para bem ou para mal, a alfabetização inculca a razão e, assim, na mesma linha do que acredita o Capitão Pratt, isso "mata o índio e salva o Homem". Deixar que os índios morressem era necessário para alcançar o progresso; além do mais, isso era feito através de tecnologias culturais, via alfabetização e urbanização. Apresentada como alfabetização e urbanização, a morte dos índios era, de fato, seu nascimento como mestiços e, somente enquanto tais, cidadãos da nação. A mesma crença se aplica para a América Latina falante do português. Segundo Azelene Kangiang, uma socióloga indígena do Brasil, no seu país, "o Estado diz para os índios: se você é incapaz e vive na floresta, então eu te protejo, se você se educa e mora na cidade, então você se torna brasileiro, e já não tem direito à sua cultura ou território" (OLIART, 2002). O que de um ponto de vista indígena expressa a negação da diferença ontológica, do ponto de vista do Estado expressa progresso, proteção e aprimoramento cultural. "Deixar os índios morrer" não era reconhecido como antagonismo até muito recentemente, quando os movimentos indígenas, utilizando-se das possibilidades de reconhecimento oferecidas nos termos do Estado - a saber, os direitos à diferença cultural —, transformaram o antagonismo em conflito político a ser negociado, levantando demandas de um Estado plurinacional. Seguindo a proposta que este ensaio desenvolve, essa pluralidade não se reduz ao multiculturalismo, mas é um projeto pelo multinaturalismo (Sobre as relações antagônicas entre indigeneidade e Estado, veja também APARICIO; BLASER, 2008).

23 Nota dos tradutores. Trecho retirado da página 447 da tradução de Raquel Camargo e Stelio Marras ao português, disponível em STENGERS, Isabelle. A proposição cosmopolítica. Revista do Instituto de Estudos Brasileiros, n. 69, p. 442-464, 2018. 


\section{Movimentos indígenas: a política através das conexões parciais}

Os indígenas da América Latina (e a indigeneidade como um campo de vida) não são, usualmente, o "inimigo" ou o "adversário" - ainda que, de fato, sejam radicalmente diferentes, eles não são completamente outros, os totalmente desconhecidos que Schmitt argumenta serem os inimigos. Tendo emergido através de fricções colaborativas (TSING, 2005) com práticas e instituições outras que as suas e, assim, incluindo essas mesmas práticas, a indigeneidade como uma formação histórica está "parcialmente conectada" com e participa das instituições dos Estados nacionais andinos. Essas instituições negam a diferença ontológica da indigeneidade, ainda que o façam através de práticas de inclusão que geralmente produzem uma conexão parcial com a diferença ontológica que elas estão dispostas a negar. "Conexão parcial", um conceito que empresto de Marilyn Strathern, aponta para uma relação que compõe um agregado que não é "nem singular, nem plural, nem um, nem muitos, um circuito de conexões mais do que partes articuladas" (2004: 54). Conexões parciais não produzem entidades singulares; a entidade que delas resulta é mais do que uma e, no entanto, menos do que duas.

Vista através das lentes das conexões parciais, a indigeneidade dos Andes - e eu me arriscaria a dizer na América Latina — pode ser conceitualizada como uma formação complexa, uma articulação histórico-política de mais do que um, mas menos do que dois mundos socionaturais. Como uma formação histórica, a indigeneidade andina não desapareceu nem no cristianismo, primeiro, nem depois na cidadania (por meio da mestiçagem); mas (como escreveu Cholango em sua carta ao Papa) também não era impermeável a eles, uma vez que isso significaria ser impermeável à história. Nem indígena, nem mestiço; estamos falando de um agregado indígena-mestiço: menos do que dois, mas não a soma das suas partes (e portanto não um "terceiro" que resulta de uma mistura), e, de fato, tampouco somente um - menos ainda um puro (DE LA CADENA, 2000). Sem produzir um fechamento, também poderíamos chamá-lo de "mestiço-indígena", dado que a ordem em que aparecessem não é teleológica. Além do mais, sua nomenclatura pode mudar, uma vez que sua forma é fractal: como fragmentos sem arestas definidas, "indígenas-mestiços" são sempre uma parte um do outro, sendo impossível a separação entre eles. Parece, então, e ainda que resista à nossa lógica, que a indigeneidade sempre foi parte da modernidade e também diferente dela; portanto nunca modernista ${ }^{24}$. Indígenas-mestiços parcialmente conectados são, como os fractais, autossimilares, ainda que, a depender do modo em que se olhe para eles, também pareçam ser diferentes (GREEN, 2005; WAGNER, 1991).

Graciano Mandura (prefeito de Ocongate, bilíngue em quéchua e em espanhol e detentor de um diploma universitário) e Nazario Turpo (pampamisayoq em Ocongate, monolíngue em quéchua e sem saber ler ou escrever) participam da indigeneidade partindo de duas posições

24 Bruno Latour talvez identificaria a indigeneidade como uma formação não moderna. Ele escreve que "um não moderno é qualquer um que tome em conta tanto a Constituição Moderna quanto o contingente de híbridos que tal Constituição rejeita e permite se proliferar" (LATOUR, 1993: 47). No entanto, não moderno sugere "unidade" [oneness], o que destoa da historicidade fractal da indigeneidade. 
diferentes - um mais capaz de valer-se da alfabetização, o outro mais apto a interagir com seres outros que humanos - mas ambos conectados aos mundos que suas vidas fazem menos do que dois. E é precisamente essa conexão parcial que deu à indigeneidade andina uma presença nas esferas políticas públicas nacional e regional: conectados aos discursos historicamente formados através dos quais eles aparecem (classe, etnicidade e a atual contraposição ao neoliberalismo) e, ao mesmo tempo, excedendo-os. O que está acontecendo, eu proponho, não é uma mudança paradigmática na história da resistência indígena; o excesso sempre esteve presente. O extraordinário disso é a sua visibilidade pública; a mudança que pode provocar seria epistêmica, e, assim, abrangeria nossas análises.

Durante a Guerra Fria, os políticos indígenas andinos articularam uma voz camponesa-operária para manifestar o conflito com o Estado nacional através da linguagem de classe e das demandas que ela permitia. As poucas etnografias produzidas no período pelos acadêmicos estadunidenses, que trabalhavam no bojo da mesma analítica de classe, identificaram o excesso, mas o circunscreveram a interpretações de solidariedade, rebelião e luta ${ }^{25}$. Após o colapso do Muro de Berlim - um símbolo da queda dos Estados socialistas e do declínio das organizações políticas marxistas - os líderes indígenas continuaram sua missão como adversários políticos valendo-se das demandas por direitos culturais. Manifestadas através da "etnicidade", as demandas políticas desse período marcaram o que alguns identificaram como o "retorno do índio" (ALBÓ, 1991), publicamente liderados por militantes de origem indígena, que rejeitaram a oferta de assimilação da cidade letrada. Em lugar disso, eles se autoidentificaram publicamente como intelectuais indígenas, um rótulo oximorônico da década de 1970 que intencionava implodir a ideia de que indígenas instruídos não eram indígenas. No mínimo bilíngues - falantes de quéchua e espanhol, por exemplo - e muitos com diplomas acadêmicos, esses políticos são considerados pelo grande público nacional como porta-vozes da indigeneidade. A despeito do seu ativismo, a fundação moderna da política tornou essa presença indígena pelo menos parcial, com os políticos modernos — os presidentes do Equador e do Peru, por exemplo — engajando-se com aquilo que entendem e ignorando aquilo que não podem entender. Frases como "os rios, peixe e floresta clamam por ajuda, mas o governo não sabe ouvir" falam tanto da impossibilidade que sustenta a relação entre indígenas e instituições políticas modernas quanto das conexões parciais que a tornam uma relação possível ${ }^{26}$. Para serem reconhecidos como adversários legítimos (cf. MOUFFE), os líderes indígenas frequentemente se pronunciam em termos modernos, traduzindo suas práticas em um discurso politicamente aceitável, e deixando "o inaceitável” em segundo plano, ainda que sem

25 Por exemplo, em sua etnografia sobre as minas bolivianas, June Nash (1993) escreve que "as cerimônias de aquecimento terrestre preparam as pessoas para um tempo em que eles podem moldar seus próprios destinos", eles "mantêm vivo o sentimento de rebelião até um momento histórico apropriado, [e] podem reforçar os movimentos políticos" (1993: 169). Identicamente, rituais são momentos "para discutir problemas e as lutas dos trabalhadores" (1993: 319). Eu não estou contestando a precisão dessa análise. Meu ponto é que a análise de classe, solidariedade entre trabalhadores e rebelião social não inclui como uma questão de política a diferença ontológica que as relações com os seres-terra trazem à tona.

26 Numa carta do líder Yanomami Davi Kopenawa "a todos os povos da terra", 31 de agosto de 1989 (GRAHAM, 2002: 181). 
abandoná-lo necessariamente (CRUIKSHANK, 2005; GRAHAM, 2002) - um ponto ao qual voltarei. A presença política da indigeneidade tem tido como pré-condição sua subordinação à cidade letrada. "Sejamos outros para que não nos ossifiquemos, mas sejamos de tal modo que não nos desfaçamos, que vocês se façam factíveis a nós": de acordo com Povinelli (2001: 329), isto é o que o liberalismo demanda da indigeneidade.

O que "não pode ser desfeita" é a política moderna; é neste sentido que a esquerda política estende requisitos análogos aos políticos indígenas. O índio permitido, para usar as palavras de Silvia Rivera (cf. HALE, 2004), não é o único que pensa a ideologia autorizada pelo Estado neoliberal; políticos de esquerda também impõem condições para aceitar os indígenas (por exemplo, para articular suas demandas com o vocabulário da luta de gênero, étnica, econômica, territorial ou ambiental). Manejando esses conceitos, os "índios" podem alcançar reconhecimento e acesso a recursos; através da agenda de esquerda as lutas indígenas têm sido, de fato, travadas e ganhas. Não obstante, classe, etnicidade, raça ou cultura (as categorias que tanto os políticos indígenas quanto os acadêmicos usam para participar e esquadrinhar a política indígena, respectivamente) funcionam no interior da divisão natureza-cultura que é perturbada epistemologicamente pela presença de Ausangate e Quilish - ou qualquer outro ser-terra - numa manifestação política. Como consequência, essas categorias podem ser insuficientes se queremos examinar a perturbação. Ao limitar a presença política dos seres-terra a manifestações de "diferenças étnicas", entramos no reduto em que é contemporaneamente renovada a hegemonia moderna que nega a diferença indígena. A "política étnica" que demanda "direitos culturais" pode abrir uma discussão e até mesmo articular a necessidade de incluir os indígenas na política - mas essa inclusão tem limites claros: seres-terra como participantes nas controvérsias são "crenças" às quais se faz jus somente quando não expressam uma alternativa epistêmica ao paradigma científico (ecológico ou econômico) e suas políticas cognatas, trabalhando para a produção do bem comum (eficiência produtiva, crescimento econômico, desenvolvimento econômico) projetado para satisfazer uma humanidade homogênea que se beneficia de uma natureza igualmente homogênea. Esses são os limites não negociáveis da Constituição Moderna (cf. LATOUR) e certamente do Estado moderno. Não surpreende, então, que esses fossem os limites a partir dos quais o presidente peruano neoliberal Alan García tenha repudiado as "montanhas sagradas" como uma invenção - e isso impedia que os especialistas de esquerda do mesmo país questionassem qualquer coisa para além de discrepâncias ideológicas.

E, no entanto, são realmente esses os limites dos processos que indivíduos como Humberto Cholango ou Nazario Turpo reivindicam? Seriam os políticos indígenas tão ingênuos a ponto de fazerem demandas que se encerram nos limites dos "direitos" assignados a eles por uma Constituição que não dá chance às diferenças vividas por eles? Eu argumentaria que é aí que o político (como o campo em que os antagonismos transparecem) começa: antes da cultura, e antes da política emergir como campo exclusivamente humano. Natureza - o que é e o que faz - não é uma entidade "apolítica" como aprendemos a pensar. Em vez disso, a sua constituição como uma esfera ontologicamente distinta está no centro do antagonismo, que continua a excluir 
"crenças indígenas" da política convencional - com a ideia de "crenças" trabalhando para obliterar a exclusão ou para estabelecer os limites internos (cf. POVINELLI, 1995) da construção ontológica da política. O que eu chamo de "indígenas-mestiços" não é somente uma identidade étnica. Parcialmente conectado com os estados nacionais andinos, "indígenas-mestiços" é uma formação socionatural vital que engloba outros que humanos, bem como sua definição da natureza e sua distinção dos seres humanos ${ }^{27}$. Quando movimentos indígenas invocam "cultura", este conceito tem a capacidade de incluir a (o que chamamos) natureza também como seres que não são humanos e aos quais não são permitidos uma voz na linguagem política estabelecida. A nova constituição equatoriana, elaborada com forte participação de políticos indígenas, é intrigante a este respeito: declara que a "Natureza" ou Pachamama (Fonte da Vida) tem direitos. Esta frase compõe uma entidade cultura-natureza que, mais complexa do que parece à primeira vista, pode pertencer a mais de um mundo e menos de dois.

Tal como utilizado pelos movimentos indígenas, "cultura" ou "natureza" não necessariamente correspondem aos nossos significados destes termos. Em vez disso, emergindo na política moderna, eles podem ser lugares de relações de equivocação no intervalo entre duas (ou mais) diferentes situações de linguagem. Equivocação, segundo Eduardo Viveiros de Castro, não é simplesmente uma falha em compreender, mas "uma falha em compreender que as compreensões não são necessariamente as mesmas, e que elas não estão relacionadas a modos imaginários de 'ver o mundo' mas aos mundos que são vistos"28 (VIVEIROS DE CASTRO, 2004: 11, ênfase adicionada). Como modo de comunicação, equivocações emergem quando diferentes posições perspectivas - visões a partir de mundos diferentes, ao invés de perspectivas sobre o mesmo mundo - usam termos homônimos para se referir a coisas que não são as mesmas. Equivocações não podem ser "corrigidas", muito menos evitadas; elas podem, no entanto, ser controladas. Isto requer atenção ao próprio processo de tradução - aos termos e suas respectivas diferenças - "para que a alteridade referencial entre as [diferentes] posições seja reconhecida e inserida na conversa, de tal forma que, ao invés de diferentes visões de um único mundo (o que seria equivalente ao relativismo cultural), uma visão de diferentes mundos se torne aparente" (VIVEIROS DE CASTRO 2004: 5, ênfase adicionada). Um exemplo pode ser necessário.

Na manifestação contra a concessão de mineração na cadeia montanhosa sobre a qual se encontra Ausangate, cartazes que diziam "Defenderemos nosso patrimônio cultural com nossas vidas. Não à mina!" chamaram minha atenção. "Patrimônio cultural" é frequentemente usado para se referir a Machu Picchu - um ícone do turismo internacional. Pensando que tal uso influenciou a decisão dos manifestantes de usar o termo, e referindo-se a ambos os lugares como atrações turísticas e ícones da herança da cultura regional, perguntei a Nazario: “Ausangate é o mesmo

27 O "indígena-mestiço" pode coincidir com a noção de plurinacional, projeto de construção da nação que os movimentos sociais indígenas no Equador e na Bolívia propõem para seus países.

28 Nota dos tradutores. Utilizamos aqui a versão da tradução ao português de Marcelo Giacomazzi Camargo e Rodrigo Amaro para VIVEIROS DE CASTRO, Eduardo. "A antropologia perspectivista e o método da equivocação controlada”, Aceno - Revista de Antropologia do Centro-Oeste, 5(10), 2018, p. 247-264. O trecho consta na página 255. 
que Machu Picchu?”. Ele respondeu: “Não, eles são diferentes. Eu conheço Ausangate muito melhor; eu sei o que ele gosta, ele me conhece também. Eu meio que conheço Machu Picchu agora porque eu vou lá com turistas. Eu estou começando a conhecê-lo. Mas eu não tenho certeza do que ele gosta, então eu faço o meu melhor para agradá-lo". Nazario não deixou de entender a minha pergunta, mas eu tive que levar em conta a equivocação. Nós estamos falando sobre as mesmas "coisas" - Machu Picchu e Ausangate. No meu mundo elas eram montanhas; para Nazario elas eram seres. Participando de nossos mundos parcialmente conectados, cada um deles era mais que uma, mas menos de duas entidades. As questões "étnicas" e "ambientais" que foram incluídas no protesto não completaram seu significado. A defesa do Santuário de Coyllur Rit'i (e de Ausangate) convocou um evento que pertencia a mais de um mundo: um preocupado com a poluição e a cultura, e o outro preocupado com a reação de Ausangate e, para alguns, ambos eram inseparáveis e, no entanto, distintos.

Pensar nas "montanhas" andinas (rotuladas de "sagradas" ou não) como locais de equivocação que permitem circuitos entre mundos parcialmente conectados sem criar um sistema de ativismo unificado, pode construir consciência das alianças também parcialmente conectadas entre ambientalistas e políticas indígenas nos países andinos, permitindo mais do que sua definição como movimentos culturais ou direitos ambientalistas. Equivocações, se controladas, podem ser análogas à forma de desacordo que Jacques Rancière identificou como central para a sua noção de política: o entendimento que ambos interlocutores fazem ou não de uma mesma coisa não é o mesmo (RANCIÈRE, 1999:xi); além de exceder a economia política, este desacordo poderia, potencialmente, trazer questões de ontologia política para o primeiro plano (ver BLASER, 2009). Quando a consciência das "montanhas" (ou de qualquer outra entidade cujo sentido não duvidamos) como equivocações não existe, as conexões parciais que sustentam o evento político (e que até mesmo o tornaram possível) desaparecem, e a disputa — por exemplo a defesa de Ausangate — é interpretada como um "problema entre duas culturas", em vez de uma controvérsia imbricada em mais do que um e menos do que muitos mundos socionaturais. Então, o destino das montanhas é facilmente definido por aquela cultura que, reivindicando princípios universais, é capaz de estender sua razão para fora do alcance das famílias do entorno, da região em que a montanha vive e para o país. Esta cultura, para viver de acordo com a responsabilidade social, também forneceria as soluções para evitar as possíveis mortes locais, valendo-se de definições como "contaminação" ou "acidentes", bem como as suas causas, por exemplo, a "negligência". O problema seria resolvido, então, apenas sob uma perspectiva, a da natureza universal. Todo perigo potencial representado, se não controlado, ao destruir montanhas para extrair metais ao passo em que se ignora o outro mundo socionatural ao qual as montanhas também pertencem, não seria um conflito político - e um de ontologia política - , mas um problema cultural em relação ao qual modernidade "sempre" mostrou indiferença, com complacência hegemônica e um suspiro resignado. Para um resultado diferente, o problema deve ser levado para um plano diferente: para o momento político que criou a divisão ontológica entre os humanos e a natureza, estendendo esta divisão para classificar outros 
mundos socionaturais e criando a política como um assunto humano alheio à natureza e confiado à representação científica. Visto deste plano histórico diferente - revelando a política epistêmica da política moderna - os conflitos potencialmente mudariam: ao invés de um problema cultural entre progresso universal e crenças locais, o destino dos outros que humanos - Ausangate por exemplo - emergiriam como um conflito entre mundos, com um deles exigindo o desentendimento simétrico. Neste ponto, a política não seria composta por relações de poder e antagonismos silenciados - estaria "composta por relações entre mundos" (RANCIÈRE, 1999: 42).

\section{"Terra" e "Meio ambiente" como equivocações}

Operar, aqui, é criar uma colocação em inquietude [mise en inquiétude] das vozes políticas, um sentimento de que elas não definem aquilo que discutem; que a arena política está povoada pelas sombras do que não tem, não pode ter ou não quer ter voz políticas [...] - Isabelle Stengers, $2005^{29}$

Participando em mais do que um, menos do que dois mundos socionaturais, os políticos indígenas são inevitavelmente híbridos, e geralmente o são sem vergonha de ser. As relações com seres outros que humanos acontecem lado-a-lado com atividades como participar em processos judiciais, organizar um sindicato de trabalhadores, participar numa ONG ambientalista e até mesmo trabalhar para uma organização capitalista. Como já disse, isso não é algo recente; a novidade está na visibilidade desse hibridismo, elemento que conduz à percepção potencial de nossas categorias analíticas como equivocações. As atividades de Mariano Turpo (pai de Nazario e, como ele, monolíngue em quéchua) nos anos 1950 e 1960 contra o dono da hacienda local é um bom exemplo; a academia das ciências sociais as descreveriam como um "movimento camponês local buscando a recuperação de suas terras comunais" ${ }^{30}$. Sim, eles eram isso - mas havia mais.

Fisicamente distante dos centros nacionais, Pacchanta - a vila em que Mariano e Nazario viveram - é atualmente um lugar dificilmente imaginável pela maioria dos intelectuais peruanos. As coisas eram diferentes nos anos 1960, quando organizações de esquerda marxista confrontaram o então prevalente sistema de haciendas por meio da organização exitosa de sindicatos camponeses. Mariano Turpo estava entre os mais conhecidos "líderes camponeses" de Cuzco. Por meio dele, Pacchanta se tornou um epicentro político em que ativistas urbanos e modernos convergiam para debater o apoio camponês para as suas agendas políticas nacionais e regionais. Como um líder

29 Nota dos tradutores. Trecho retirado da página 447 da tradução de Raquel Camargo e Stelio Marras ao português, disponível em STENGERS, Isabelle. A proposição cosmopolítica. Revista do Instituto de Estudos Brasileiros, n. 69, p. 442-464, 2018.

30 Entre as primeiras análises da "luta camponesa pela terra", ver Wilson Reategui (1977); entre as mais recentes, veja Renique (2004). 
sindical, Turpo era um ativista ubíquo, movendo-se incansavelmente entre a cidade e o campo ele organizou a celebração de Primeiro de Maio, dia do trabalho no Peru, coletou cotas de outros camponeses que ele chamava de companheiros (seus parceiros de luta), confrontou fisicamente os homens de hacienda, escondendo-se deles nas cavernas de Ausangate e de outras montanhas, participou e até discursou em manifestações na Plaza de Armas del Cuzco - o mesmo lugar onde, quarenta anos depois, Nazario e eu participaríamos da manifestação para defender Ausangate.

Juntamente com o ativismo político, Mariano continuou suas práticas como um pampamisayoq, interagindo com os seres-terra que cercam Pacchanta. Além disso, as duas atividades não estavam separadas. Elas se desdobravam por meio de relações que ignoravam a distinção entre os mundos natural e social dado que concebia o poder como forças conectadas à paisagem socionatural circundante, emanando tanto dos seres-terra - montanhas, lagos e vento detentores de intenção - quanto das instituições sociais e dos indivíduos: representantes do Estado, camponeses, comerciantes locais e políticos. Mariano queria "recuperar a terra" para o seu ayllu. Mas essa frase excedia os termos de sua aliança com os ativistas de esquerda. Ayllu é uma palavra em quéchua que elicia as relações entre seres humanos e outros que humanos que interagem num território dado, marcando-o como um lugar específico ${ }^{31}$. Justo Oxa, um professor de educação básica cuja língua materna é o quéchua e se autoidentifica como indígena, escreve:

\begin{abstract}
A comunidade, o ayllu, não é somente um território onde um grupo de pessoas vive; é mais do que isso. Ele é um espaço dinâmico em que vive a comunidade inteira de seres que existem no mundo; isso inclui os humanos, as plantas, os animais, as montanhas, os rios, a chuva, etc. Tudo está relacionado como uma família. É importante lembrar que esse lugar [a comunidade] não é o lugar do qual somos, ela é quem somos. Por exemplo, Eu não sou de Huantura, eu sou Huantura (OXA, 2004: 239, ênfase minha).
\end{abstract}

A terra que a hacienda tinha tomado era o ayllu (não do ayllu) "desde o tempo dos Incas" (como Mariano e outros explicariam), e isso impactou todos os seres que compunham o lugar. "As ovelhas estavam morrendo, nós não tínhamos pastos, nós não podíamos criá-las - as batatas não cresciam na terra que nos deixaram. Tanto a terra quanto as sementes estavam tristes. Nossas crianças estavam tristes. Ninguém conseguia comer — nós estávamos vivendo uma vida agonizante. Ausangate nos ignorava porque não nos importávamos com ele ou com nossa vida - para novamente poder cuidar, criar os animais, nossos filhos e uns aos outros, e também respeitar Ausangate, nós tínhamos que ser corajosos e confrontar o dono da hacienda", lembrava-se Mariano. À sombra do "movimento camponês de retomada das terras", e sustentando-o, estava o entrelaçamento de relações entre seres humanos e outros que humanos heterogêneos que tornava a vida possível no território que a hacienda também ocupava, de maneiras que negavam essas

31 A noção de ayllu como incluindo outros que humanos é onipresente na etnografia andina. Ver especialmente Allen (2002), Harris (2000) e Ricard-Lanatta (2007). Nos documentos oficiais e nos jornais, no entanto, a palavra é geralmente traduzida como grupo de parentesco, território e, no melhor dos casos, como uma justaposição de ambos. 
práticas. Em quéchua, tais práticas são conhecidas como uyway, uma palavra que os dicionários traduzem para o espanhol como "criar hijos, hacer crecer las plantas y los animales [criar filhos, fazer as plantas e os animais crescerem]" (ITIER, n.d.). Incorporada nas práticas cotidianas, uyway se refere às relações de cuidado mútuo entre humanos e também com seres outros que humanos. Mais uma vez, Justo Oxa escreve:

respeito e cuidado são parte fundamental da vida nos Andes; eles não são um conceito ou uma explicação. Cuidar e ser respeitoso significa querer ser nutrido e ser cuidado ${ }^{32}$ e nutrir e cuidar de outros, e isso implica não só os humanos, mas todos os seres do mundo... cuidado-nutrição ou uyway dá cor à toda a vida andina. Pachamama nos cuida e nos nutre, o Apus nos cuida $\mathrm{e}$ nos nutre, eles cuidam de nós. Nós cuidamos e nutrimos nossos filhos e eles nos cuidarão e nos nutrirão. Nós cuidamos e nutrimos as sementes, os animais e as plantas, e eles nos cuidam e nos nutrem também" (OXA, 2004: 239).

A possibilidade de retomar práticas de cuidado entre seres humanos e outros que humanos também motivou a luta de Mariano contra a hacienda. "Alimentando o espírito da montanha, os produtores camponeses também asseguram que o espírito da montanha os alimentará", escreveu Michael Taussig depois de ler várias etnografias sobre os Andes (TAUSSIG, 1980: 144). No entanto, para os aliados de Mariano na década de 1960, políticos da esquerda moderna, considerar essas ideias seriamente era impensável. Trabalhos etnográficos eram precisamente o lugar ao qual essas práticas pertenciam - não à política. Mariano estava ciente daquilo que seus parceiros de esquerda sentiam, mas ele colaborou com as práticas políticas deles e isso tornou um sucesso o combinado esforço classista-indígena de "recuperar a terra". Mas "terra" era uma equivocação. Era um termo homônimo que permitia a dois mundos parcialmente conectados lutarem conjuntamente pelo mesmo território. O feito tornou-se publicamente conhecido como o fim do sistema de hacienda e o começo da Reforma Agrária. O fato de que o mundo de Mariano tivesse recuperado o ayllu - em sua implicação relacional - continuou desconhecido, nas sombras a partir das quais tal mundo tornou esse evento histórico possível.

Sob a orientação de seu pai, Nazario também se tornou um pampamisayoq. Nesse papel, ele era (entre outras coisas) um defensor dos esforços de base para proteger os seres-terra dos arredores contra a mineração em potencial. Eu não estou dizendo que o Nazario atuou como um guardião de tradições intocadas. Ainda que nunca tenhamos conversado sobre isso, eu tampouco acho que

32 Nota dos tradutores. "Ser nutrido e ser cuidado" é a escolha que fizemos para tratar da expressão em inglês "to be nurture". Qualquer tradução única do termo nurture para o português parece insuficiente para dar conta da amplitude conceitual que ele carrega no interior do relacionalismo radical da autora. De forma geral, o termo implica tanto aquilo que entendemos como "nutrição" quanto as práticas de cuidado e criação que formam pessoas. Neste sentido, o termo implica uma imbricação entre o cultural e o natural, e entre o construído e o inato, pares importantes para a crítica da tradição antropológica que leva à virada ontológica, da qual de la Cadena, de algum modo, participa. A inspiração para o tratamento dado ao termo vem das elaborações de Jamille Pinheiro, Iracema Dulley e Luísa Valentini sobre suas opções tradutórias para "O Efeito Etnográfico",de Marilyn Strathern. Ainda que as tradutoras da antropóloga britânica variem sua escolha para nurture entre educação, criação ou nutrição, a depender do contexto e mantendo o termo em inglês entre colchetes, nossa opção neste artigo foi adotar "cuidado e nutrição", ao mesmo tempo, como tradução para o termo. 
ele era contra a economia de mercado: ele trabalhou para uma agência de turismo bem-sucedida com a ajuda da qual ele estava traduzindo suas práticas como "Xamanismo Andino", um campo novo e florescente para o consumo dos turistas e uma nova fonte de renda para camponeses e pastores como ele. Em todo caso, Nazario era, como seu pai, um inovador: um cosmopolita local articulando outros mundos, e novas práticas, em seu próprio mundo, encontrando os termos de alianças que melhor pudessem beneficiar suas vidas. Não era à mineração em si mesma que ele e o resto das pessoas com as quais falei se opunham. A mineração como uma atividade econômica tem sido parte da vida dos camponeses andinos desde a Conquista, e aqueles que habitam o entorno de Ausangate estão familiarizados com a prática de garimpo de ouro na Madre de Dios, uma região cordilheira-abaixo com condições vergonhosas de trabalho. No entanto, há uma importante diferença entre as tecnologias mais antigas de mineração e aquelas utilizadas pelas corporações que atualmente prospectam a região que Ausangate dirige. As primeiras seguiam os veios do mineral explodindo as rochas sólidas com dinamites e perfurando túneis no interior das montanhas. Atualmente, as corporações são conhecidas por suas tecnologias de mineração a céu aberto, as quais literalmente destroem montanhas em um curto período de tempo — por vezes em menos de um ano. Essas diferenças têm consequências: enquanto a escavação de túneis permite a continuidade das relações com os seres-terra, a mineração a céu aberto destrói os próprios seres-terra $^{33}$. Nazario estava preocupado com o tipo de relações que poderia se desdobrar entre Ausangate (o ser-terra) e a mina. Vividos a partir de seu mundo, os perigosos empreendimentos da mineração corporativa não só invadem as terras camponesas e poluem o meio-ambiente; eles também destroem um mundo socionatural.

No mundo de Mariano e Nazario Turpo, as habilidades políticas incluem as relações entre seres humanos e outros que humanos que têm lugar junto: montanhas, rios, plantações, sementes, ovelhas, alpacas, lhamas, pastos, parcelas de terra, rochas - até cachorros e galinhas ${ }^{34}$. E como o novo Estado neoliberal (incapaz de enxergar tais relações) recusa esse lugar, o abstrai e o reterritorializa legalmente (por exemplo, declarando-o como espaço "vazio" ou "improdutivo") para abrir espaço para a mineração e para os benefícios econômicos que potencialmente geraria, pessoas como Nazario e Graciano se preocuparam com a destruição do seu lugar, trazendo sua preocupação para a política. Obviamente, uyway - relações de cuidado mútuo entre seres humanos e outros que humanos - não são o único tipo de relações mobilizadas para a política. Juntamente com suas preocupações sobre a ira de Ausangate, Graciano Mandura mencionou a poluição como um problema, assim como o dano potencial que a mina poderia causar ao turismo na área. Nazario compartilhava desse receio, dado que o turismo era uma fonte fundamental de

33 As relações com o Tio, o ser parecido com o diabo que habita as minas bolivianas, ilustram o ponto (ver NASH, 1993; TAUSSIG, 1980).

34 Emprestado de Ingold (2000), pode-se dizer que essas relações são "habilidades de habitar" [ $d$ welling skills]: interações entre humanos e não humanos em que ambos são um com o outro e em que a vida é concebida relacionalmente. Veja também Feld e Basso (1996). As habilidades de habitar do Mariano e do Nazario Turpo incluíam conexões parciais com atividades e instituições políticas modernas. 
sua renda monetária. Evidentemente, preocupar-se com os serres-terra e o lugar não está em desacordo com o desejo de bem-estar econômico. Ademais, entre os camponeses também estão aqueles que ficam do lado da mina — talvez até pampanisayoq o façam (ainda que eu não tenha topado com nenhum). Não existe uma coesão simples para qualquer movimento, nem mesmo montanhas poderosas poderiam provê-la. No entanto, de modo análogo à "terra" como um equívoco que possibilita a aliança entre políticos de esquerda e camponeses indígenas ao mesmo tempo em que oclui as relações de cuidado entre montanhas-animais-plantações-humanos, quando se trata da luta antimineração na região de Ausangate (e em outros lugares), há mais do que a defesa da natureza num movimento ambientalista. Também uma equivocação, o "meio-ambiente" engloba os seres-terra; no entanto, diferentemente do confronto com a hacienda, quando os seres-terra eram apenas uma questão de preocupações locais, atualmente eles aparecem nas arenas políticas nacionais e até mesmo internacionais.

A incursão dos empreendimentos de mineração capitalista em áreas geográficas que essas corporações e o Estado consideram remotas, improdutivas e vazias tornaram os seres-terra mais públicos do que nunca na última metade do século - uma consequência que o neoliberalismo não antevia. Na sua tese doutoral, Fabiana Li (2009) analisou o processo através do qual uma montanha do norte dos Andes peruanos, o Cerro Quilish, tornou-se protagonista de uma controvérsia que colocou camponeses e a ONG ambientalista que os apoiarava contra a companhia de mineração transnacional, proprietária de Yanacocha, a maior mina de ouro da América Latina e uma das maiores do mundo. Uma questão central na controvérsia era a ontologia do Cerro Quilish. Para a companhia de mineração, a montanha era principalmente um repositório de ouro - quatro milhões de onças do metal; para os ambientalistas e muitos fazendeiros que se opunham à mina, Quilish representava uma fonte de água para a agricultura local. Um padre da região, que ali viveu por um longo período e estava ciente da relação dos camponeses com a montanha como ser-terra, a traduziu como uma "montanha sagrada". Muitos dos oponentes da mina se distanciaram dessa definição e enfatizaram a importância da montanha como um aquífero; no entanto, o aspecto "sagrado" de Quilish se juntou às suas já atraentes qualidades naturais. Transformada numa robusta entidade natural-cultural, Quilish chamou a atenção dos ambientalistas nos Estados Unidos e na Europa, fortalecendo a já robusta oposição nacional à companhia de mineração Yanacocha.

Fenômeno totalmente coetâneo - e de modo algum um ressurgimento milenarista ou restaurador de arcaicas práticas populares - o aparecimento dos seres-terra na política confronta diretamente as tecnologias que ameaçam destruir lugares que, até o momento deste surto tecnológico atual, e que depois da expansão mineradora do século XIX, permaneceram relativamente marginais ao capital. Confrontando o capital corporativo, o Estado neoliberal e suas consequências interligadas na produção de mundos, a presença pública dos seres-terra na política é parte e parcela dos processos globais que provocaram os debates acadêmicos sobre "formas de vida emergentes" (FISCHER, 2003) e "aglomerados globais" (ONG; COLLIER, 2005). Cavar uma montanha para abrir uma mina, perfurar o subsolo para encontrar petróleo e cortar árvores para 
extrair madeira poderiam produzir mais do que simples danos ambientais ou crescimento econômico. Tais atividades poderiam traduzir-se na violação de redes de conformação de lugares que tornam a vida localmente possível - e até mesmo na destruição desses lugares. Em tais casos, eles se encontraram com uma oposição ampla e, às vezes, surpreendentemente bem-sucedida, que abriu a disputa (ainda impensável para mentes modernas) entre seres-terra locais e a "Natureza" universal, algumas vezes recrutando ambientalistas na negociação. Assim, os conflitos políticos em curso são fora do comum. Em alguns casos, o rótulo de "guerra" (inicialmente usado para referir os confrontos em torno da água e do gás na Bolívia, nos anos 2000) é talvez apropriado para designar alguns dos conflitos correntes.

Maio de 2008, Sucre, Bolívia. Um grupo grande de cidadãos indígenas, que chegaram numa longa marcha vinda do campo para se encontrar com Evo Morales, o Presidente aymara do país, e para celebrar as festas pátrias, foram atacados por um grupo de residentes urbanos que, indiferentes às câmeras que documentavam o evento, insultaram os manifestantes indígenas de animais, os despojaram de suas roupas e emblemas e, uma vez despidos, os forçaram a declarar sua obediência ao Estado nacional não indígena imaginado por esses citadinos (El Correo del Sur [Sucre], 25 de maio de 2008). A violência desse episódio foi assustadora - física e conceitualmente. Ela apontava para um momento em que, recusando-se a aceitar o fim da biopolítica racista que regeu o país até recentemente, as classes dominantes regionais decidiram matar indígenas abertamente, entendendo-os como usurpadores do poder que as elites haviam exercido por séculos. No entanto, como sugeri anteriormente, não foi apenas a intolerância aos humanos e seus corpos que motivou essas ações. Meses antes, o seguinte comentário apareceu num jornal local:

O governo do MAS, todo ele, seus ministros, representantes no parlamento e na assembleia constituinte, fala como múmias... seus homens sábios cortam a garganta de lhamas, queimam coca e acendem fogo sagrado no saguão principal do Palácio Governamental. Então, quando tudo está em silêncio, e somente se escuta o som do pututo (corneta de concha de caramujo), eles fazem os rituais para os seus deuses, a fim de que Evo Morales se torne imortal [Manfredo Kempff Suárez, "escritor e diplomata", assina como autor, La Razón (La Paz), 2 de outubro de 2007).

Conceitualmente, o evento expressou mais do que racismo; existem muitas razões políticas relevantes para a violência que parecem óbvias na Bolívia, mas central dentre elas é a de que os mundos indígenas estão fazendo uma reivindicação a partir do próprio coração do Estado, e, assim, revelando o antagonismo biopolítico que regeu a Bolívia até 2006, e, o que é pior, possivelmente transformando-o em relações contraditórias. A guerra silenciosa pode se tornar política e isso não pode ser tolerado “antes uma guerra explícita do que política” é a resposta aparente de um grupo não tão pequeno da elite. 


\title{
Um final em aberto: política plural em um pluriverso político
}

\author{
O ponto não é que os cientistas tenham de aceitar qualquer \\ coisa que essas pessoas empoderadas digam, o ponto é que \\ aprender com elas é a chance de colocarem suas ideias \\ preconcebidas em risco \\ - Isabelle Stengers, $2002^{35}$
}

Eu não quero ser mal interpretada. Ser uma "intelectual engajada" — una intelectual comprometida - foi o jeito que eu vivi no Peru e isso continua marcando meu trabalho acadêmico. Na verdade, minhas redes se misturaram às de Mariano Turpo por causa de seu papel na política moderna - um ativista desconhecido no movimento que produziu uma das mudanças mais importantes no Peru contemporâneo. Por isso, minha discussão aqui não tem a intenção de subtrair o ativismo engajado, mas de acrescentar a ele. Da mesma maneira, espero não ser interpretada apenas como uma defensora da condição singular ou perfeita dos "povos indígenas". O que eu estou tentando fazer aqui é seguir a proposta de Isabelle Stengers para "desacelerar o raciocínio", a fim de deixar a composição daquilo que não tem voz política (ou, em alguns casos, não quer ter uma) afetar a minha análise e, como ela sugere na citação acima, colocar minhas ideias preconcebidas em risco para fazer a Antropologia dizer algo diferente - ou abri-la para além do nosso mundo, para uma Antropologia dos mundos. Trabalhando com Mariano e seu filho Nazario, aprendi sobre a colonialidade da política e dos muitos e complexos recursos dos quais deriva sua hegemonia. Um recurso óbvio é a qualidade letrada da política, moldada pelo papel da cidade e seu legado intelectual. Naturalmente, os melhor educados ocupam lugar mais alto na escala da política; as exceções - aqueles que não têm diploma universitário, como o presidente boliviano Evo Morales - são vistas como anomalias e objeto de escândalos. No melhor dos casos, tendemos a pensar que o escândalo (e a "deficiência" que isto denota) pode ser facilmente superado, talvez através de alianças com os mais instruídos. Mais uma vez, a Bolívia vem à mente, e pensamos em Álvaro García Linera, o atual vice-presidente deste país e sociólogo, como a cabeça pensante por trás do presidente, o intelectual orgânico trabalhando em colaboração horizontal com intelectuais de todas as outras áreas, desconsiderando suas posições. Como uma ilustração da prática gramsciana contemporânea, poderíamos até sentir orgulho disso.

O problema surge, entretanto, quando tal colaboração esquece que política (enquanto categoria e prática) foi historicamente inabilitada para trabalhar em simetria com a radical diferença que a própria modernidade produziu entre os muitos mundos que habitam o planeta. A política emergiu (com a ciência) para criar um universo habitável, para controlar conflitos entre 
uma humanidade culturalmente diversificada, vivendo em uma única natureza cientificamente cognoscível. A consequência disso não é apenas que a política é letrada, o problema é que ela só pode admitir humanos em seu domínio - ponto final. Analogamente à ciência dominante, que não permite que seus objetos falem, a política hegemônica diz aos seus sujeitos o que eles podem trazer para a política e o que devem deixar para os cientistas, mágicos, sacerdotes ou curandeiros — ou, como tenho argumentado, o que devem deixar habitar nas sombras da política ${ }^{36}$. Por que montanhas não podem ser trazidas para a política (a não ser por meio da ciência), a parceria de Nazario com Ausangate é apenas folclore, crença que pertence à outra "cultura", que pode ser felizmente mercantilizada como uma atração turística, mas em nenhum caso considerada na esfera política. Esta exclusão não é apenas racismo; ela expressa o acordo consensual que fundamenta a política. As exclusões que resultam disso são impossibilitadas de se traduzirem em desentendimentos políticos porque não contam — de modo algum. Uma vez implementado com a ajuda da História, interromper este acordo para fazer com que as exclusões contem como tais, parece uma tarefa anacrônica impossível (CHAKRABARTY, 2000). Afinal, a política moderna oferece inclusão... em seus próprios termos.

Refutar essa inclusão, recusando ter a voz que a política lhes oferece e, ao mesmo tempo, intervindo nela, é o que líderes locais como Mariano têm feito, frequente e invisivelmente, há algum tempo. Atualmente, no entanto, os seres-terra estão se tornando mais visíveis na política e muitas vezes em seus próprios termos. Se desacelerarmos, suspendermos nossas suposições e as ideias que acarretam, poderíamos perceber como esta emergência altera os termos do político; como perturba o consenso que barrou práticas indígenas da política, atribuindo-as à religião ou ao ritual e obliterou tal exclusão. Podemos usar esta oportunidade histórica para colocar nossas ideias preconcebidas em risco e renovar nossas ferramentas analíticas, nosso vocabulário e outros enquadramentos semelhantes.

Ainda assim, esta oportunidade só existe se estivermos dispostos a desistir de duas velhas respostas (e medos), que se espelham mutuamente: (1) políticas indígenas são tradicionais e arcaicas, e, portanto, perigosas, uma vez que podem evoluir para um fundamentalismo antidemocrático (o espectro da "balcanização" — e da recente "bolivianização" — assombrando senhores e senhoras mergulhados no liberalismo), ou, no outro polo do espectro, (2) as políticas indígenas são essencialmente boas e nós devemos defendê-la (o fantasma do bom selvagem incomodando os ingenuamente íntegros).

Eu propus que o atual surgimento da indigeneidade andina poderia forçar a pluralização ontológica da política e a reconfiguração do político. Há várias coisas, no entanto, que esta frase não quer dizer ${ }^{37}$. Primeiro, isto não se refere à pluralidade ideológica, de gênero, étnica, racial ou mesmo religiosa; nem se refere à incorporação ou inclusão de diferenças marcantes em uma socialidade multiculturalmente "melhor". Em segundo lugar, não é uma estratégia para ganhar

$36 \quad$ Bruno Latour (1997).

37 Eu devo essa frase à Mario Blaser, um de meus parceiros intelectuais. 
hegemonia ou ser uma maioria dominante - muito menos uma maioria indígena. Minha proposta de pensar por meio da pluralização da política não se destina a corrigir falhas dentro da política já existente - ou a "política como de costume". Em vez disso, visa transformar o conceito que concebe a política como disputas de poder dentro de um mundo singular, levando a outro, que inclui a possibilidade de relações contraditórias entre mundos: uma política pluriversal.

Para pensar tal possibilidade, eu construí meus argumentos, tanto a partir da noção de Carl Schmitt do político como um pluriverso, quanto do conceito de política de Jacques Rancière como divergência entre mundos. Tomando emprestado de Viveiros de Castro (2004) e Strathern (2004), penso no pluriverso enquanto mundos socionaturais heterogêneos, parcialmente conectados, negociando politicamente seus desacordos ontológicos - o que implicaria em maiores conflitos, a importância política da discussão seria superlativa, mas substituiria a atual guerra não reconhecida e suas ocasionais erupções públicas. A ideia de um pluriverso é de fato utópica: não porque outras formações socionaturais e suas práticas da terra não acontecem, mas porque aprendemos a ignorar suas ocorrências, considerando-as uma coisa do passado ou, o que dá no mesmo, uma questão de ignorância e superstição. Assim, ao contrário de utópica, minha proposta é, nas palavras de Stengers (2005), um projeto idiota: meu objetivo não é induzir à ação, mas, mais uma vez, desacelerar o raciocínio e provocar o tipo de pensamento que nos permitiria desfazer, ou mais precisamente, desaprender, a ontologia única da política.

Isso exigiria duas etapas na reconceitualização do (que Mouffe chama de) político antes da política pluriversal ter início. O primeiro passo é reconhecer que o mundo é mais do que uma formação socionatural; o segundo é interconectar tal pluralidade sem tornar os diversos mundos comensuráveis. O processo utópico é, portanto, a redefinição da linha de base do político, a partir de onde a política começou, com uma definição hegemônica que abrigava a superioridade da formação socionatural do Ocidente e suas práticas, para uma que começa com uma compreensão simétrica dos mundos plurais, suas formações socionaturais e suas práticas. A partir da linha de base anterior (ou melhor, a que estamos acostumados), a política aparece como um negócio entre humanos depois de negar a copresença ontológica de outras formações socionaturais e suas práticas, e traduzir a negação, com o uso da história universal, a partir de uma manobra antagônica - uma declaração de guerra contra os mundos considerados inferiores - em uma condição necessária para uma ordem mundial boa e habitável. A nova linha de base é precisamente a quebra do silêncio, tornar público o antagonismo para possibilitar sua transformação em agonismo. Neste ponto, ao invés da guerra biopolítica que tanto o liberalismo quanto o socialismo travaram contra seus ditos "outros", uma nova configuração política pluriversal - talvez uma cosmopolítica, nos termos de Stengers - conectaria mundos diferentes com suas formações socionaturais - tudo com a possibilidade de se tornarem adversários legítimos não apenas dentro dos Estados nacionais, mas também em todo o mundo.

Em um nível mais concreto, uma política pluriversal (ou uma cosmopolítica) aceitaria o que chamamos de natureza como uma multiplicidade, permitindo que as visões conflitantes 
sobre essas multiplicidades sejam discutidas. Isto é, penso eu, o que o líder equatoriano Humberto Cholango propôs em sua carta ao papa: ele primeiro denunciou o antagonismo entre as instituições modernas e as relações indígenas com seres outros que humanos, e depois traduziu esse antagonismo em um conflito político com a capacidade de interpelar atores indígenas e não-indígenas. No caso específico da mina que ameaçava Ausangate, uma ordem política pluriversal, competentemente fluente em multiplicidade, levaria a sério (digo, antes literalmente, ao invés de metaforicamente), tanto a relação de Nazario Turpo com Ausangate como uma entidade intencional, quanto sua definição como natureza e um repositório potencial de ouro. Os diferentes mundos nos quais Ausangate existe seriam publicamente permitidos, não sendo colocados em equivalência de qualquer tipo, e então, políticas - amargas discrepâncias entre diferentes, talvez irreconciliáveis interesses ideológicos, econômicos, culturais ou de qualquer outro tipo - começariam. Alguns ficariam ao lado de Nazario, outros se oporiam a ele. Em vez de recusada como superstição, ou "respeitada" como cultura, com uma política pluriversal, a questão de Ausangate como um ser passaria a contar. Incluído no desentendimento, poderia então contestar (ou talvez concordar) com, por exemplo, propostas de crescimento econômico e desenvolvimento, ou com questões de justiça social e igualdade. Livre de sua representação exclusiva como "Natureza", as múltiplas e heterogêneas ontologias da montanha (incluindo seu potencial como repositório de riqueza mineral), também pesariam em projetos políticos heterogêneos sem necessariamente incliná-los para a esquerda ou para a direita.

A política pluriversal adiciona uma dimensão de conflitos e eles não têm garantias ideológicas ou étnicas (cf. HALL, 1996). Pessoas — indígenas ou não, e talvez etnicamente não rotuladas - poderiam ficar do lado da mina, privilegiando empregos e dinheiro ao invés de Ausangate, seja porque eles duvidam ou até negam publicamente a existência de uma montanha dotada de intenções, seja porque eles estão dispostos a arriscar sofrer a ira do ser-terra por uma vida diferente. A obstinação de Ausangate poderia ser derrotada no processo político — alguns poderiam abraçá-la, outros não - mas o fato de ele ser outro que uma montanha não seria mais silenciosamente negado, pois uma política pluriversa estaria habilitada para reconhecer o conflito como algo emergente entre mundos parcialmente conectados. Embora eu não seja capaz de me traduzir na ontologia de Nazario, nem de saber, como ele, que a ira de Ausangate é perigosa, eu ficaria do lado dele porque quero o que ele quer: ser considerado em pé de igualdade frente aos demais, denunciar o abandono que o Estado tem relegado a pessoas como ele - ao mesmo tempo em que ameaça com a assimilação — denunciar os empreendimentos de mineração que não se importam com a vida local; em poucas palavras, para defender em sua maneira, em minha maneira e na maneira que possa emergir como nosso o lugar em que Nazario vive.

Um posfácio de última hora. No amanhecer do dia 5 de junho de 2009, aconteceu um confronto violento entre forças policiais e um grupo grande de cidadãos peruanos, autoidentificados como pertencendo ao grupo indígena Awajún-Huambisa. O objetivo da polícia era interromper um bloqueio 
numa das principais estradas, próxima à cidade de Bagua, nas terras baixas da Amazônia, norte do Peru. Os Awajún-Huambisa tomaram a estrada como parte de uma greve geral, que começou no dia 9 de abril, organizada por vários grupos indígenas amazônicos. O confronto produziu muitas mortes - os números oficiais contabilizaram 23 policiais e 10 indivíduos Awajún-Huambisa. De acordo com a contagem local, o número de mortos chega a centenas, a maior parte deles indígenas.

O conflito começou um ano antes. Entre maio e junho de 2008, Alan García emitiu 101 decretos de leis com a intenção de facilitar a concessão de territórios amazônicos a companhias petroleiras, madeireiras e hidroelétricas. Em agosto de 2008, uma greve indígena bem-sucedida forçou o Congresso Nacional a pedir que o Presidente peruano cancelasse os decretos. Ele ignorou a decisão — os protestos indígenas recomeçaram no ano seguinte. Dessa vez, o protesto alcançou audiências internacionais, uma vez que os políticos indígenas acusavam o Presidente de violar a Convenção 169 da OIT, que exige que os Estados consultem os povos indígenas a respeito das mudanças por ocorrer nas terras que eles habitam. A consulta não foi levada a cabo, o governo violou um acordo de caráter constitucional e, então, os decretos tinham de ser anulados. Se consultados, tal grupo político, que o presidente havia identificado como de esquerda, teria refutado os decretos. Ainda assim, as razões não eram unicamente ideológicas:

Nós falamos pelos nossos irmãos que saciam a nossa sede, que nos banham, que protegem nossas necessidades - esse [irmão] é o que chamamos de rio. Nós não usamos o rio para despejar nossas imundícies; um irmão não pode apunhalar outro irmão. Nós não apunhalamos nossos irmãos. Se as corporações transnacionais se preocupassem com nossa terra como nós nos preocupamos ao longo dos milênios, nós com prazer abriríamos espaço para que elas pudessem trabalhar aqui - mas tudo com o que eles se preocupam é seus benefícios econômicos, para encher seus cofres com riquezas. Nós não entendemos por que o governo quer destruir nossas vidas com esses decretos [Los Sucesos de Bagua, http://www.servindi. org/producciones/videos/13083, acessado em 20 de junho de 2009].

Leni, um jovem líder Awajún - sua cara pintada de vermelho e preto, uma bandana ao redor da cabeça - proferiu as palavras acima em meio à greve. Seu mundo, em que rios e humanos são irmãos, é de fato completamente coetânea com aquelas das corporações. Mas, estas últimas matam os rios; para evitar essa matança, os políticos indígenas se mobilizaram contra os decretos legislativos (aqueles que queriam destruir os modos de vida indígenas, segundo Leni) e tornaram o antagonismo num conflito político aberto; "se o governo cancela os decretos hoje, nós deixamos a área", disse outro entrevistado sobre a duração da greve (http://www.servindi.org/producciones/videos/13083, acessado em 20 de junho de 2009). O governo rejeitou o conflito político, e, em vez disso, mandou as forças policiais para esmagar o movimento. $\mathrm{O}$ resultado foi o sangrento confronto de 5 de junho, entre civis e as forças policiais, cujas 
notícias logo viajaram pelo mundo. No dia 19 de junho, o congresso cancelou os decretos, mas os líderes indígenas tiveram que se esconder - parece que finalmente o antagonismo já não é mais silencioso. Se a liderança indígena terá sucesso em transformar a defesa de seu mundo e seus seres em uma questão política, em uma relação contraditória antagônica com o mundo hegemônico, é uma questão incerta. Um evento fundamentalmente transformativo, isso de fato desafiaria a política universal.

\section{Notas}

Reconhecimentos. Embora esteja assinando como autora deste ensaio, as ideias que apresento resultam de colaborações com vários amigos. Mario Blaser, Arturo Escobar, Penny Harvey, Nazario Turpo e Margaret Wiener são meus coautores silenciosos. Fabiana Li compartilhou comigo sua tese quando ela ainda estava em curso; eu retiro dela a maior parte do que eu sei sobre o Cerro Quilish. Conversas com María Puig della Bellacasa confirmaram o valor do trabalho de Isabelle Stengers para além dos estudos da ciência. Orin Starn tem sido uma presença crítica constante, mesmo que ele não saiba. Finalmente, muitos leram este ensaio. Eu devo um agradecimento especial a Claudia Briones, Paulo Drinot, Joe Dumit, Cristiana Giordano, Gillian Goslinga, Kregg Hetherington, Suad Joseph, Caren Kaplan, Alan Klima, Kristina Lyons, Rossio Motta, Hortensia Muñoz, Bettina Ng'weno, Deborah Poole, Dana Powell, Magali Rabasa, Bruno Rvesz, Justin Richland, Steve Rubenstein, Guillermo Salas, Mike Savage, Suzana Sawyer, Isabelle Stengers e Eduardo Viveiros de Castro. Versões anteriores foram apresentadas na University of Manchester, Duke University, University of California, Davis, Cultural Studies Program, University of California, Irvine, e na University of Oregon at Eugene. E para Kim Fortun e Mike Fortun: seu cuidado integral foi essencial a esse ensaio.

\section{Referências Bibliográficas}

ABERCROMBIE, Thomas. Pathways of Memory and Power: Ethnography and History among an Andean People. Madison: University of Wisconsin Press, 1998.

ALBÓ, Xavier. El retorno del indio. Revista Andina, v. 9, p. 299-366, 1991.

ALBRO, Robert. The Culture of Democracy and Bolivia's Indigenous Movement. Critique of Anthropology, v. 26(4), p. 387-410, 2006.

ALLEN, Catherine. The Hold Life Has. Coca and Cultural Identity in an Andean Community. Washington, DC: Smithsonian Institution Press, 2002.

ALONSO, Ana María. Conforming Disconformity: "Mestizaje," Hybridity, and the Aesthetics of Mexican Nationalism. Cultural Anthropology, v. 19(4), p. 459-490, 2004. 
America. Anthropological Quarterly 81(1):59-94, 2008.

ASAD, Talal. Reflections on Laicité and the Public Sphere. Items and Issues, v. 5(3), p. 1-11, 2005.

BEBBINGTON, Anthony \& BURNEO, María Luisa. Conflictos mineros: Freno al desarrollo o expresión ciudadana. Presentation at University of North Carolina, September, 2008.

BLASER, Mario. Bolivia: Los desafíos interpretativos de la coincidencia de una doble crisis hegemónica. Reinventando la nación en Bolivia: Movimientos sociales, Estado y poscolonialidad. MONASTERIOS, Karin; STEFANONI, Pablo \& DO ALTO, Hervé (Orgs.), p. 11-21. La Paz: CLACSO/Plural, 2009.

. The Threat of the Yrmo: The Political Ontology of a Sustainable Hunting Program. American Anthropologist, v.111(1), p. 10-20, 2007.

CHAKRABARTY, Dipesh. Provincializing Europe. Princeton: Princeton University Press, 2000.

CÓRDOBA, José de \& LUHNOW, David. A Dash of Mysticism: Governing Bolivia the Aymara Way. Wall Street Journal, July 6, 2006.

CRUIKSHANK, Julie. Do Glaciers Listen. Local Knowledge, Colonial Encounter and Social Imagination. Vancouver: University of British Columbia Press, 2005.

DE LA CADENA, Marisol. Indigenous Mestizos: The Politics of Race and Culture in Cuzco, Peru 1919-1991. Durham: Duke University Press, 2000.

DESCOLA, Philippe. In the Society of Nature. A Native Ecology in Amazonia. Cambridge: Cambridge University Press, 1996.

. "No Politics Please." Making Things Public: Atmospheres of Democracy. Bruno Latour and Peter Weibel, p. 54-57. Cambridge, MA: MIT Press, 2005.

DINWOODIE, David W. Authorizing Voices: Going Public in an Indigenous Language. Cultural Anthropology, v. 13(2), p. 193-223, 1998.

EARLS, John. The Organization of Power in Quechua Mythology. Journal of the Steward Anthropological Society, v. 1, p. $63-82,1969$.

FELD, Steven \& BASSO, Keith. Senses of Place. Santa Fe: School of American Research Press, 1996. 
FISCHER, Michael M. J. Emergent Forms of Life and the Anthropological Voice. Durham, NC: Duke University Press, 2003.

FLORES-OCHOA, Jorge ed. Pastores de Puna; uywamichiq punarunakuna. Lima: Instituto de Estudios Peruanos, 1977.

FOUCAULT, Michel. Society must de defended. Lectures at the Collège de France 1975-1976. New York: Picador, 2003.

FRASER, Nancy. Rethinking the Public Sphere: A Contribution to the Critique of Actually Existing Democracy. Justice Interruptus: Critical Reflections on the "Postsocialist" Condition. Nancy Fraser, p. 69-98. New York: Routledge, 1997.

GRAHAM, Laura. How Should an Indian Speak? Brazilian Indians and the Symbolic Politics of Language Choice in the International Public Sphere. Indigenous Movements, Self-Representation and the State in Latin America. Jean Jackson and Kay Warren, p. 181-228. Austin: University of Texas Press, 2002.

GREEN, Sarah. Notes from the Balkans. Locating Marginality and Ambiguity on the

Greek-Albanian Border. Princeton: Princeton University Press, 2005.

GOSE, Peter. Deathly Waters and Hungry Mountains: Agrarian Ritual and Class Formation in an Andean Town. Toronto: University of Toronto Press, 1994.

HALE, Charles R. Rethinking Indigenous Politics in the Era of the "Indio Permitido" in Nacla. Report on the Americas, v. 38(2), p. 16-21, 2004.

. Activist Research v. Cultural Critique: Indigenous Land Rights and the Contradictions of Politically Engaged Anthropology. Cultural Anthropology, v. 21(1), p. 96-120, 2006.

HALL, Stuart. The Problem of Ideology: Marxism without Guarantees. Critical Dialogues in Culture Studies. D. Morley and K.-H. Chen, p. 25-46. London: Routledge, 1996.

HARAWAY, Donna J. Simians, Cyborgs, and Women: The Reinvention of Nature. New York: Routledge., 1991.

HARRIS, Olivia. To Make the Earth Bear Fruit: Ethnographic Essays on Fertility, Work, and Gender in Highland Bolivia. London: Institute of Latin American Studies, 2000. 
HARVEY, Penelope. Civilizing Modern Practices. Response to Isabelle Stengers. Paper presented at the106th Annual Meeting of the American Anthropological Association, Washington, D.C., November 28-December 2, 2007.

HEGEL, G. F. W. Lectures on the Philosophy of World History. Race and the Enlightenment: A Reader. Chukwudi Eze Emmanuel, p. 109-153. Cambridge, MA: Blackwell, 1997 [1822].

HILSON, Gavin \& HASELIP, James. The Environmental and Socioeconomic Performance of Multinational Mining Companies in the Developing World Economy. Minerals and Energy, v. 19(3), p. 30-45, 2004.

INGOLD, Tim. The Perception of the Environment. New York: Routledge, 2000.

ITIER, Cesar. Diccionario Quechua-Castellano, seguido de un indice Castellano-Quechua. Unpublished MS, N.d.

JACKSON, Jean. Preserving Indian Culture: Shaman Schools and Ethno-Education in the Vaupes, Colombia. Cultural Anthropology, v. 10(3), p. 302-329, 1995.

LATOUR, Bruno. We Have Never Been Modern. Cambridge, MA: Harvard University Press, 1993.

Foreword. Stengers’s Shibboleth. Power and Invention. Situating Science. STENGERS, Isabelle \& BAINS (Orgs.). Minneapolis: University of Minnesota Press, 1997.

Politics of Nature: How to Bring the Sciences into Democracy. Cambridge, MA: Harvard University Press, 2004.

. From Realpolitik to Dingpolitic or How to Make Things Public. Making Things Public. Atmospheres of Democracy. LATOUR, Bruno \& WEIBEL, Peter. (Orgs.), p. 14-43. Cambridge, MA: MIT Press. 2005.

LI, Fabiana. When Pollution Comes to Matter: Science and Politics in Transnational Mining. Ph.D. Tese, Anthropology Department, University of California, Davis, 2009.

MAYER, Enrique. Peru in Deep Trouble: Mario Vargas Llosa's “Inquest in the Andes" Reexamined. Cultural Anthropology, v. 6(4), p. 466-504, 1991.

MOUFFE, Chantal. On the Political. New York: Routledge, 2000.

NASH, June. We Eat the Mines and the Mines Eat Us. Dependency and Exploitation in Bolivian Tin Mines. New York: Columbia University Press. 1993 [1979]. 
NELSON, Diane M. Stumped Identities: Body Image, Bodies Politic, and the Mujer Maya as Prosthetic. Cultural Anthropology, v. 16(3), p. 314-353, 2001.

OLIART, Patricia. Identidad indígena e historias de contacto en América Latina. Paper presented at the Race and Culture in Latin America conference, University of Iowa, Iowa City, p. 22-25, 2002.

ONG, Aiwa \& COLLIER, Stephen. Global Assemblages. Technology, Politics and Ethics as Anthropological Problems. Oxford: Blackwell, 2005.

OSPINA, Pablo. Ecuador: Al Ritmo de la iniciativa política del gobierno de la revolución ciudadana. Quito: CEP, 2008.

OXA, Justo. Vigencia de la Cultura Andina en la Escuela. Arguedas y el Perú de Hoy. Carmen María Pinilla: Lima: SUR, 2004.

PLATT, Tristan. The Sound of Light: Emergent Communication through Andean Shamanic Dialogues. Creating Context in Andean Cultures. R. Howard-Malverde, p. 196-226. Oxford: Oxford University Press, 1997.

POVINELLI, Elizabeth. Do Rocks Listen? The Cultural Politics of Apprehending Australian Aboriginal Labor. American Anthropologist, v. 97(3), p. 505-518, 1995.

. Radical Worlds: The Anthropology of Incommensurability and Inconceivability. Annual Review of Anthropology, v. 30, p. 319-334, 2001.

RAMA, Angel. The Lettered City. Durham, NC: Duke University Press, 1996.

RANCIÈRE, Jacques. Disagreement: Politics and Philosophy. Minneapolis: University of Minnesota Press, 1999.

REATEGUI, Wilson. Explotacion Agropecuaria y las Movilizaciones Campesinas em Lauramarca Cusco. Lima: Universidad Nacional Mayor de San Marcos, 1977.

RENIQUE, Jose Luis. La batalla por puno. Conflicto Agrario y Nacion en los Andes Peruanos. Lima: IEP, Sur, CEPES eds, 2004.

RICARD-LANATTA, Xavier. Ladrones de Sombra. Cuzco: Cera Las Casas, 2007.

SALLNOW, Michael. Pilgrims of the Andes. Regional Cults in Cusco. Washington, DC: Smithsonian Institutions Press, 1987. 
SCHMITT, Carl. The Concept of the Political. Chicago: University of Chicago Press, 1996.

SHAPIN, Steven \& SCHAFFER, Simon. Leviathan and the Air Pump: Hobbes, Boyle, and the Experimental Life. Princeton: Princeton University Press, 1985.

STARN, Orin. Missing the Revolution: Anthropologists and the War in Peru. Cultural Anthropology, v. 6(1), p. 63-91, 1991.

STENGERS, Isabelle. The Cosmopolitical Proposal. Making Things Public: Atmospheres of Democracy. LATOUR, Bruno \& WEIBEL, Peter. (Orgs.), p. 994-1004. Cambridge, MA: MIT Press, 2005.

STEPHENSON, Marcia. Forging an Indigenous Counterpublic Sphere: The Taller de Historia Oral Andina in Bolivia. Latin American Research Review, v. 37(2), p. 99-118, 2002.

STRATHERN, Marilyn. Partial Connections. New York: AltaMira, 2004.

TAUSSIG, Michael. The Devil and Commodity Fetishism in South America. Chapel Hill: University of North Carolina Press, 1980.

TSING, Anna. Friction: An Ethnography of Global Connection. Princeton: Princeton University Press, 2005.

VALDERRAMA, Ricardo \& Carmen Escalante. Del Tata Mallku a la Pachamama: Riego, Sociedad y Rito en los Andes Peruanos. Cuzco: CERA Bartolomè de las Casas, 1988.

VIVEIROS DE CASTRO, Eduardo, Perspectival Anthropology and the Method of Controlled Equivocation. Tipití. Journal of the Society for the Anthropology of Lowland South America, v. 2(1), p. 3-22, 2004.

WAGNER, Roy. The Fractal Person. Big Men and Great Men: Personifications of Power. In Melanesia. STRATHERN, Marilyn \& GODELIER, Maurice (Orgs.), p. 159-173. Cambridge: Cambridge University Press, 1991.

WILLIAMS, Raymond. Marxism and Literature. London: Verso, 1977. 